\title{
The Charity of the Extremely Wealthy
}

\author{
Tom Coupe \\ Kyiv School of Economics/ Kyiv Economics Institute \\ Claire Monteiro \\ Georgetown University
}




\title{
The Charity of the Extremely Wealthy
}

\begin{abstract}
In this paper we show that, compared to billionaires who have inherited their wealth, billionaires who have made their own wealth are more likely to sign the Giving Pledge and more likely to be in the Million Dollar Gifts lists or the Philanthropy Top 50 list of big givers. If they give, self-made billionaires also tend to donate more money. We explore several possible explanations for this correlation between the origin of billionaires' wealth and their charitable giving, and present evidence that suggests that self-made billionaires tend to spend more money, both by giving money away and by buying expensive items.
\end{abstract}

JEL Codes: D03, H40

Keywords: billionaires, Forbes, charitable giving 
"Our experience worldwide is that first-generation wealth is actually more generous than dynastic wealth ... Both here in India and U.S. and other countries, the biggest givers are those who are receivers of first-generation wealth." (Bill Gates quoted in Thakur et al, 2011)

\section{Introduction}

In this paper, we study the charitable behavior of billionaires, focusing on the impact of the source of their wealth on their charitable donations and pledges. While billionaires play a leading role in both the economy and in philanthropy, and they are watched closely by journalists and the public at large, econometric studies that focus on the behavior of billionaires are $\operatorname{rare}^{1}$.

Understanding the charitable behavior of the extremely wealthy is important because they are responsible for a disproportional share of overall giving, directly through the amounts of money they give and also because their public status makes their behavior an example for others to follow. While the determinants of individual giving have already been studied in experimental settings and using surveys (Steinberg et al., 2011, Reinstein and Riener, 2012), this paper documents charitable behavior of a larger magnitude than that typically studied in experiments, and of people who do not participate in experiments or fill out surveys ${ }^{2}$.

Our analysis focuses on the question of whether self-made billionaires are more charitable than billionaires who inherited their money, as Bill Gates suggested in the quote above. It is welldocumented that people's decisions on how to spend money often depend on how they received that money. Epley et al. (2006), for example, show that the propensity to consume is bigger if income received is framed as a bonus rather than a rebate. Arkes et al. (1994) show that windfall gains are more readily consumed than non-windfall gains. Such evidence has been found both inside and outside the laboratory, but in this paper we investigate whether treatment of income

\footnotetext{
${ }^{1}$ A recent descriptive analysis of the Forbes 400 wealthiest Americans and their background can be found in Kaplan and Rauh (2013). Many empirical papers have tried to explain why some countries have more billionaires than others (e.g. Neumayer, 2004 or Leeson and Sanandaji, 2013).

${ }^{2}$ Andreoni (2006), in his review of the literature on charity, has a section on giving by the very wealthy and notes that "Despite their importance, there are few studies of giving by the very wealthy. This is because data is scarce." There is, however, a body of literature on estate and inheritance taxes which uses administrative data to study the behavior of rich and very rich people (see f.e. Kopczuk, 2013 for a review) including how these taxes affect charitable behavior. This literature does not focus on billionaires (though some billionaire estates are included in the analysis) nor does (or can) it investigate how the source of wealth affects giving behavior given that data on the source of wealth are not readily available.
} 
varies depending on its source when the amounts at stake are much larger than previously studied in the literature. In this paper, amounts range from millions to billions of dollars, in comparison with the tens or hundreds of dollars in experimental literature, or the tens of thousands of dollars studied in the research on decisions in every-day life. Moreover, studies that investigate how spending varies with the source of money typically conclude that earned income is spent more carefully than windfall gains. However, in the case of charitable giving, self-made money seems to be more, rather than less likely to be spent on charity than inherited money. Steinberg et al. (2011) indeed show, using data from the charitable giving module of the Panel Study of Income Dynamics (PSID), that the presence of inherited wealth increases giving but also that "income held constant, an increase in the proportion of income coming from an inheritance is associated with a decrease in charitable giving" 3 .

To study the charitable behavior of the extremely wealthy we use data from the Giving Pledge, a global public pledge to give away at least half of one's fortune during one's lifetime (http://givingpledge.org/), which by now has been signed by more than 100 extremely wealthy people (typically current billionaires). In addition, we use data on the presence of U.S. billionaires in the Philanthropy Top 50 and in the Million Dollar List, a list of those who have given grants of 1 million or more since 2000 .

We find evidence that self-made billionaires are three to four times more likely to sign the Giving Pledge and to enter the Philanthropy Top 50 list of biggest pledges, compared with those who inherited their wealth. At the same time, we find that the gap in probabilities between self-made and inherited wealth is much smaller, at about $28 \%$, when looking at the presence in the Million Dollar List. We also find that self-made billionaires give more on average than inherited billionaires do, when measuring total gifts using the Million Dollar List or the Philanthropy Top 50.

We then investigate some possible reasons for why the source of wealth might matter for billionaires' charity. We check whether the correlation between source of wealth and charity continues to be significant after controlling for demographic factors or the extent of billionaires' networks.

We find that some demographic factors indeed matter for giving (richer and older billionaires donate more, and billionaires in some industries donate more than billionaires in other

\footnotetext{
${ }^{3}$ The average wealth in the Steinberg et al. (2011) sample is about 350,000, with about 50,000 coming from inheritance.
} 
industries) and that self-made billionaires tend to be more networked. We also find evidence that being more connected to other billionaires goes together with being more generous. Most importantly, however, controlling for these demographic or network factors in our regression analysis does not affect our conclusion that self-made billionaires are significantly more likely to sign the Giving Pledge and are significantly more likely to be present in the Philanthropy Top 50 and, to a lesser extent, in the Million Dollar List.

We also investigate whether our finding could be the result of self-made billionaires being more public rather than more charitable. We find that Forbes indeed knows more about selfmade billionaires. Controlling for the information that is known by Forbes, however, does not affect our general conclusion about the importance of self-made wealth for charity. We further present evidence that self-made billionaires are more likely to spend money on big-ticket items like private yachts, private jets, or expensive art suggesting that self-made billionaires are relatively more prone to spending money, both by giving it away and by buying expensive consumption items.

Besides contributing to the literature on charitable giving and the literature on billionaires, our analysis also leads to several policy implications. First, Leeson and Sanandaji (2013) provide evidence which suggests political institutions affect the chance that self-made billionaires are able to develop. They find that there are more self-made billionaires in countries where private property is supported and market-enhancing institutions exist. If self-made billionaires are indeed more inclined toward philanthropy than inherited billionaires, then governmental policies that hamper new entrepreneurial billionaires emerging will affect the occurrence of major charitable gifts. This is both because there will be fewer billionaires over time, and also because gradually the only billionaires that will remain will be inherited billionaires. More generally, any policy that affects the relative balance of inherited versus self-made billionaires is likely to affect charitable giving.

Second, our results are consistent with the anecdotal evidence that self-made billionaires do not want to "spoil" their children by bequeathing them with too much money (see for example, Roberts, 2014) and that those who inherited themselves want to pass this inheritance to their children (see for example, Ostrower, 1995) ${ }^{4}$. Our finding that self-made billionaires are more charitable but also are more likely to consume big ticket items suggests that earned money is less likely to be bequeathed because earned money is spent more, not only on consumption but

\footnotetext{
${ }^{4}$ More generally, Wilhelm et al. (2008) find that children's giving correlates with their parents' giving.
} 
also on giving to charity. If billionaires want their children to start their careers under similar circumstances to their own, and giving money to charity is one of the ways to achieve this, then policy interventions that affect charitable giving (like those affecting bequests) would not only have an effect on the charitable giving of current billionaires but also on the giving of their offspring. Hence, such policies can have a long run impact.

The latter also implies that acting fast matters. Many emerging markets present favorable environments for new billionaires to arise, but at the same time miss a legislative framework that facilitates charity (Milner, 2012). If the lack of framework prevents billionaires (both selfmade and inherited) from giving, then governments of emerging markets better improve their legislation quickly to benefit from the higher generosity of the newly rich before they pass their riches on to their children whom will become inherited millionaires or billionaires.

In Section II we present a descriptive analysis that shows that, on average, self-made billionaires are more generous. In Section III we use regression analysis to investigate whether this finding remains after controlling for demographic factors and network variables. In Section IV we conclude and discuss the policy implications.

II. Descriptive statistics on the link between charity and the source of billionaires' wealth

To study the link between the origins of billionaires' wealth and their charitable behavior we combine data from several sources.

To identify who is a billionaire and what is the source of their wealth, we use the 2013 Forbes' Billionaire list, which profiles 1,426 billionaires. Forbes distinguishes two sources of wealth, self-made wealth and inherited wealth. Self-made wealth is the wealth of those who did not inherit a business or a large amount of money. Those who inherited large amounts of money, or a company which they then developed into a billion dollar business-empire, are included in the inherited wealth category ${ }^{5}$.

\footnotetext{
${ }^{5}$ Forbes categorization is not entirely uncontroversial, as some claim that "The Forbes 400 list is carefully constructed to reinforce the 'rags to riches' narrative. Each story calculatedly glamorizes the myth of the 'selfmade man' " (United for a Fair Economy, 2012). If we compare the classification of Forbes, with the classification of Kaplan and Rauh (2013), using the 361 U.S. billionaires for which data from both sources are available, we find $95 \%$ of billionaires is classified in the same way.
} 
Data on participation in the Giving Pledge comes from the Giving Pledge website ${ }^{6}$ and from the Glasspockets website, ${ }^{7}$ a website that tracks the performance of the Giving Pledge participants. By 2013, 114 individuals had signed the Giving Pledge - out of these, 85 (or about $6 \%$ of all billionaires) are in the 2013 Forbes Billionaires list, and another 14 were in the Forbes list at some point in time before 2013. Using Forbes' categorization of sources of wealth, about $67 \%$ of the billionaires in the Forbes 2013 list are self-made. Interestingly, of the 85 signatories of the Giving Pledge, only 10 have inherited wealth while 75 are self-made. This corresponds to a $2 \%$ participation rate for the inherited billionaires, against an $8 \%$ participation rate for the self-made billionaires. This six-percentage-point difference means that self-made billionaires are four times more likely to sign the Giving Pledge than the inherited billionaires.

One could argue that we should restrict the sample to U.S. citizens only, as before 2013, nonU.S. citizens were not eligible to sign the Giving Pledge (and even now U.S. citizens represent the large majority of Giving Pledge signatories). If we make this restriction, we find that 6 out of $129(4.7 \%)$ inherited billionaires and 65 out of 313 (20.8\%) self-made billionaires signed the Pledge. As with the full sample, self-made billionaires are about 4 times more likely to sign the Giving Pledge than inherited billionaires among the U.S. citizens.

Additional information about the charitable activities of the U.S.-based billionaires in the Forbes 2013 list can further be obtained from the Philanthropy Top 50 lists of the Philanthropy Chronicle, which identifies the top 50 biggest pledges by Americans each year since 2000. 8,9 Out of the 2013 Forbes billionaires, 94 made the top 50 list in one of the years between 2000 and 2012. Eighty-two of these are self-made, 12 are inherited billionaires, making self-made billionaires about 3 times more likely to be in that list (26.2\% versus $9.3 \%)$.

The above measures focus on extreme forms of charity of the extremely wealthy, pledging to give away half of one's fortune or making multimillion dollar pledges. To study the more moderate forms of giving, we collected data on the presence of the U.S. billionaires in Indiana University's Million Dollar List (http://www.milliondollarlist.org/). The Million Dollar List records publicly reported gifts of $\$ 1$ million or more since 2000 , with a focus on giving in the U.S. Out of a total of 68,767 gifts of 1 million or more, we could connect 8,179 gifts to U.S.

\footnotetext{
${ }^{6} \mathrm{http}$ //givingpledge.org/

7 http://glasspockets.org/givingpledge/

8 The Giving Pledge pledges are not taken into account in this ranking.

${ }^{9} \mathrm{http}: / /$ philanthropy.com/section/Philanthropy-50/370/
} 
billionaires who were on the 2013 Forbes $\operatorname{list}^{10}$. Of the inherited billionaires, $48.1 \%$ have recorded gifts of 1 million or more, while $61.7 \%$ of self-made billionaires have given such gifts. Hence, the difference in relative probabilities between inherited wealth and self-made wealth is much smaller when examining Million Dollar gifts in comparison with Giving Pledge commitments or Philanthropy Top 50 donations. While self-made billionaires are three to four times more likely to be in the Philanthropy Top 50 or the Giving Pledge List, self-made billionaires are only $28 \%$ (or 13.6 percentage points) more likely to be in the Million Dollar List.

[Table 1 about here]

Table 1 brings together the above evidence on the difference in charitable giving depending on the origin of the billionaires' wealth. It provides information about both the percentage of billionaires that gives as well as the amounts of money given. It shows that self-made billionaires on average also give substantially bigger amounts than inherited billionaires do, based both on the amounts from the Philanthropy Top 50 and the Million Dollar List.

In the next section, we study possible explanations for this correlation between source of wealth and charitable behavior.

III. Possible explanations for the correlation between source of wealth and charitable behavior

So far we have shown that, on average, self-made billionaires are more likely to pledge big gifts to charity than are billionaires who inherited their fortune. We next discuss a number of possible explanations for this difference in charitable behavior.

First, self-made billionaires and inherited billionaires might differ in terms of demographic characteristics, such as age, marital status or citizenship - characteristics which have been found to be related to charitable giving. For example, married people, more wealthy people, older people, people with higher education, and people born in the U.S. tend to give more (see Havens et al., 2006).

\footnotetext{
${ }^{10}$ We automatically matched billionaires' last names to the names on the Million Dollar donor list and manually cleaned the list. We exclude donations to one's own foundation to avoid double counting, and exclude donations by one's family foundation except if the family foundation was founded by the billionaire her/himself. Corporate donations are excluded. Donations attributed to several people were allocated proportionally.
} 
To check this we will include, in the regression analysis below, background indicators on the billionaires provided by Forbes. In its annual list, Forbes includes, besides the (estimated) net worth of an individual (and the corresponding rank within the Billionaire list), information about the age, the marital status, the number of children, the country of citizenship, the education, and the source of wealth of the billionaires.

Second, who gives does not only depend on the characteristics of the givers but also of those who approaches the billionaires. As the Giving Pledge is an initiative of two self-made billionaires, Bill Gates and Warren Buffett, self-made billionaires could just have been more likely to be invited to sign the Pledge. According to one account of that first meeting at which Bill Gates and Warren Buffett discussed charitable giving with other billionaires, almost all guests of that first meeting were self-made billionaires (Loomis, 2010), though the event was hosted by David Rockefeller Sr., an inherited billionaire ${ }^{11}$. Hence, self-made billionaires might have simply preferred to ask other self-made billionaires or more generally, self-made billionaires might be better connected (and hence more likely to be approached by those soliciting gifts) than inherited billionaires ${ }^{12}$.

To investigate this network explanation, we collected information about non-profit memberships of billionaires from the littlesis.org website. Littlesis.org "is a free database detailing the connections between powerful people and organizations" and has detailed information about positions and memberships in non-profit organizations of many billionaires ${ }^{13}$. From Littlesis.org we have information about non-profit positions, in a total of 462 different organizations, for 296 billionaires of the 2013 Forbes list. The other billionaires either do not hold such positions in the organizations covered by Littlesis or are not known to hold such positions. Littlesis.org focuses on membership of U.S.-based organizations so it is not surprising that 241 out of the 296 billionaires included are U.S.-based billionaires.

Through "interlocking" memberships, billionaires can be connected to each other ${ }^{14}$. To test formally the role of networks, we include the overall number of billionaires to whom a

\footnotetext{
11 Though the "invitation letter went to more people than could come" (Loomis, 2010).

12 One argument against the network explanation is that we not only find a difference between self-made and inherited wealth in the Giving Pledge (for which we have a clear story in support of a network effect) but also in the Philanthropy Top 50 list and the Million Dollar List, lists for which such a network story is not immediately available.

${ }^{13}$ We used the Forbes 2012 list (2013 is not available) of littlesis.org (http://littlesis.org/list/260/The_World\%27s_Billionaires___Forbes_\%282012\%29) which includes info for about 300 billionaires and linked this to the 2013 billionaires list. Mainly U.S. billionaires are included.

${ }^{14}$ For example, Bill Gates is member of 5 organizations. Through these 5 organizations he is connected with twenty other billionaires. Eighty percent of the billionaires he is connected with are self-made billionaires, $25 \%$
} 
billionaire is connected through interlocking membership as a variable in the regression analysis.

Third, one could argue that self-made billionaires are more likely to sign the Giving Pledge or contribute a big gift is not because self-made billionaires are more generous, but rather that they are more public about their charity ${ }^{15}$. The Giving Pledge is, by design, a public declaration of one's generosity, something that might come naturally to self-made business people for whom being public (and advertising themselves) has been part of their business career, but might come much less naturally to those who inherited their fortune.

To test whether self-made billionaires give less anonymously, we would need information about anonymous donations ${ }^{16}$. While there is anecdotal evidence about some billionaires trying to keep their charitable contributions anonymous ${ }^{17}$, we, almost by definition, do not have such information for the vast majority of the billionaires.

There is some evidence, however, that more could be known about self-made billionaires than about inherited millionaires. For example, one indicator of the extent to which a billionaire is public is the extent to which Forbes has information about them: while for about 44 percent of inherited billionaires Forbes misses information about age, education or relationship status, for only about 30 percent of self-made billionaires this info is missing ${ }^{18,19}$. To control for

\footnotetext{
have signed the Giving Pledge, 30\% are on the Philanthropy Top 50 list and 60\% have given million Dollar gifts. Overall, we find that self-made and inherited billionaires are about as likely to be members of non-profits (21.1\% versus $20.1 \%$ ) but that conditional on being member of a non-profit organization, self-made billionaires are members of more organizations (3.2 versus 2.4). Self-made and inherited billionaires are about as likely to be at least connected to one other billionaire (conditional on being a board member in at least one non-profit, about $80 \%$ ). However, conditional on being connected, self-made billionaires on average (but not in terms of median) are connected to more other billionaires than inherited billionaires. The reason for this is that some self-made billionaires are connected to very large numbers of other billionaires. There is little evidence, however, that billionaires primarily network with people who have a similar source of wealth: the share of self-made billionaires in one's network is similar for both self-made and inherited billionaires. For details, see the online appendix OA1.

${ }^{15}$ Admittedly, we investigate a non-exhaustive list of possible explanations. Other explanations include that self-made billionaires "pledge" more but do not actually give more since they might be more likely not to fulfill their pledges (unfortunately, no information is available about non-fulfillment of pledges), that inherited billionaires could have a stronger precautionary savings motive and only give at the end of their life, or that they could expect or face different 'death taxes'.

${ }^{16}$ An analysis of (small) anonymous donations for the London Marathon can be found in Peacey and Sanders (2012).

${ }^{17}$ Laurene Powell Jobs, the widow of Steve Jobs, runs her charity through an LLC, like a small business - this allows her not to have to report publicly the donations she makes (Miller (2013)).

${ }^{18}$ We do not include missing children as missing info on children is shown as zero children in the Forbes database.

${ }^{19}$ Regressing a dummy reflecting missing information on demographic characteristics and the self-made dummy confirms more is known about self-made billionaires. See online appendix AO2.
} 
differences in the level of "publicness" we include "missing" dummies which take value 1 if information on a given variable is unavailable, and zero otherwise.

Because more information is available for the U.S. billionaires (Forbes, Littlesis.org, the Philanthropy Top 50 and the Million Dollar List all have more information available on U.S. billionaires), we will focus in the analysis below on the results for the regression analysis using data from U.S. billionaires only ${ }^{20}$.

In the regression analysis, we use several dependent variables. We use a Logit regression analysis to model the probability of signing the Giving Pledge, of being included in the Philanthropy Top 50 (at least once between 2000 and 2012) and of being included in the Million Dollar Gifts list (at least once between 2000 and 2013). We use Tobit regressions to model the amount of gifts based on the latter two criteria ${ }^{21}$.

Table 2 gives the descriptive statistics for the explanatory variables used in the regression analysis. Our main variable of interest is the dummy for the source of wealth, taking the value of 1 for self-made billionaires. Seventy one percent of US billionaires are classified as selfmade. The regression further controls for the net worth of the billionaire (in billions of 2013 U.S. Dollars, 4.2 billion on average) and the number of billionaires to which the billionaire is connected through interlocking non-profit board memberships (on average, 4 connected billionaires). The regression also controls for the industry in which the billionaire is active (7 categories) ${ }^{22}$, her/his age (in years, on average, U.S. billionaires are 66 years old), and

\footnotetext{
${ }^{20}$ For U.S. billionaires, Forbes misses information about age, education or relationship status for only about $2 \%$ of self-made and $9 \%$ of inherited billionaires. To minimize missing information and to distinguish between no children and information about children missing, we used internet searches to fill in as much missing information as possible. After filling in information, we have missing education for about $4 \%$ of U.S. billionaires and the exact number of children missing for about $2.5 \%$.

${ }^{21}$ We collapse several years of data from the Philanthropy Top 50 , and similarly for the Million dollar list, into the overall amount for the whole period. We do this for several reasons. First, the number of billionaires in the Top 50 or giving Million dollar gifts in a given year is small (raising concerns about rare event bias in logit (King and Zenge, 2001)) and imperfectly measured (so the variable "having given over a period" is likely to contain less error than the variable "having given in a specific year"). Second, most explanatory variables either do not vary over time (like source of wealth), vary little over time (like marital status) or are hard to obtain in panel data form (like the network variable, the marital status, etc.). Third, it is unlikely that short run changes in explanatory variables like wealth have an immediate effect on giving. The above reasons complicate a fixed effects panel data analysis and make it of little use for the question we focus on (since source of wealth is fixed over time). This comes at a cost, however: for the Tobit regressions, we use as truncation values the lowest observed cumulative amounts over the period 2000-2012/2013 as truncation points. In reality, truncation happens on a yearly basis rather than cumulative. An analysis like the above, using yearly data for both wealth and donations, for the 167 U.S. billionaires that are present both in 2001 and 2013, leads to similar conclusions as the ones presented here. See online appendix AO3 for details.

${ }^{22}$ We aggregated Forbes 24 categories into 7 categories: "Business \& Diversified \& Finance \& Investments ," "Fashion and Retail \& Retail \& Food and Beverage," "Automotive and Manufacturing \& Construction and
} 
relationship status (a dummy that is 1 if the billionaire is in a relationship, with about $80 \%$ of U.S. billionaires in a relationship). The regression further includes a dummy for family wealth that takes the value 1 if Forbes indicates the net worth belongs to an individual and his/her family (rather than just the individual) or to more than one individual. Finally, we control for highest obtained education with the following categories: less than BA (which includes dropouts), BA, M(B)A, or Ph.D. Given that not all information is available for all billionaires, we include a missing education dummy (for the billionaires for whom no information on education is available), a missing relationship dummy (for the billionaires for whom no relationship status is available), and a missing age dummy (for the few billionaires for whom no age is available).

[Table 2 here]

Table 3 shows the results of the regression analysis. We find that, even after controlling for various factors, self-made billionaires are significantly more likely to give and that they give significantly more. In comparison with inherited billionaires on the Forbes 2013 list, self-made billionaires are about 19 percentage points more likely to be signatories of the Giving Pledge and are about 19 percentage points more likely to have been at least once in the Philanthropy Top 50 between 2000 and 2012. Self-made billionaires are also about 6 percentage points more likely to have made at least one million dollar gift in the period 2000-2013, though the latter estimate is not significantly different from zero. The Tobit regressions further show that the latent variable reflecting the amount given is between 2 (Million Dollar Gifts) and 5 (Philanthropy Top 50) times higher for self-made billionaires, as compared to inherited billionaires ${ }^{23}$.

[Table 3 about here]

We also find that more connected billionaires, wealthier billionaires, and older billionaires tend to be more likely to give, and to give larger amounts. Depending on the specification, each additional billion in net worth increases the likelihood of giving by between 0.4 and 1.5 percentage points, and increases the latent variable reflecting the amount given by about 13 percent. Each connection and each year of age have somewhat smaller effects. Finally, energy-

Engineering \& Real Estate," "Media," "Telecom \& Technology," "Logistics \& Health care \& Gaming \& Sports \& Service \& Medicine \& Politics," "Energy \& Oil \& Metals and Mining."

${ }^{23}$ Since the dependent variable is in logs, these numbers are obtained by plugging in the coefficients and standard errors of table 2a in the formula in Kennedy (1981). 
sector billionaires as well as Technology/Telecom sector billionaires tend to be more generous than those who have earned their wealth in other sectors.

As a first robustness check, table 4 shows a regression using the Giving Pledge as dependent variable and using the available data from billionaires worldwide (rather than US billionaires only in table 3). We find that self-made billionaires are about 5 percentage points more likely to sign the Giving Pledge. Hence, the qualitative conclusions based on data from billionaires worldwide confirms the results from the analysis based on data from only US billionaires ${ }^{24}$.

[Table 4 about here]

Additional robustness checks using the sample of US billionaires do also not alter the conclusion that self-made billionaires appear to be more generous ${ }^{25}$.

First, including different or additional network variables does not affect our conclusion that self-made billionaires are more generous. In contrast to the earlier network measure of connections, we checked whether being on a nonprofit board with Warren Buffet or Bill Gates affects the probability of signing the Giving Pledge. We further ran regressions in which we split up the total number of billionaires in one's network into a count of the self-made billionaires in one's network and a count of the inherited billionaires. In another set of regressions, we split up the total number of billionaires in one's network into a count of billionaires who give and those who do not give. None of the above specifications affects our conclusion that self-made billionaires are more generous.

Second, we also checked whether the effect of demographic characteristics differ across inherited and self-made billionaires. For example, there is some anecdotic evidence that some self-made billionaires do not want to bequeath their children with too much money (see for example Roberts, 2014) and there is evidence that those who have inherited money also want to or feel they have to pass on money to their children (for example, Arrondel et al., 1997, or Ostrower, 1995)). If parents indeed prefer their children to be in a similar situation at the start of their careers as they were themselves, one should observe that inherited billionaires with children limit their charity while self-made billionaires should try to prevent their children from inheriting a lot of money by giving it away (or by spending their money in other ways). At the same time, we should not observe a difference between self-made and inherited billionaires

\footnotetext{
${ }^{24}$ See Online Appendix OA4 for the descriptive statistics of variables used in this regression.

25 The table with results for these robustness checks are available in an online appendix AO5.
} 
who do not have children. Unfortunately, there are too few U.S. billionaires without children to check the second part of this hypothesis. Limiting the sample to billionaires with children indeed shows a positive estimate of the self-made dummy, however.

Third, to check whether self-made billionaires also spend more on other things than charity, we searched the internet for Forbes billionaires owning very big ticket items like yachts, jets, and expensive art. ${ }^{26} \mathrm{We}$ found 64 billionaires who own yachts, 57 who bought expensive art in 2013, and 38 who own private jets. As can be seen from Table 5, self-made billionaires are more likely to own yachts, jets, or expensive art than inherited billionaires, suggesting that selfmade billionaires are indeed spending more of their wealth than inherited billionaires on very big ticket items. At the same time, the gap between inherited and self-made billionaires is substantially bigger for the Giving Pledge or the Philanthropy Top 50.

[Table 5 about here]

A regression analysis similar to table 3 but using very big ticket consumption as a dependent variable shows that self-made billionaires tend to be more prone to consuming very big ticket items than inherited billionaires (though the difference is not always significant). Including the dummy for very big ticket consumption ( 1 if a billionaire consumes at least one of the three big ticket items) in the regressions with different dimensions of generosity as a dependent variable does not affect our conclusion, however, that self-made billionaires are substantially more generous than inherited billionaires are ${ }^{27}$.

\section{Discussion and Conclusions}

In this paper, we analyze the charitable behavior of billionaires, people who are not only important because of the amounts of money they give, but also because many ordinary people see them as role models. Consistent with the literature on the charity of ordinary people, we find that billionaires who have more money and who are older tend to be more likely to give to charity.

\footnotetext{
${ }^{26}$ Most information about yachts came from http://www.superyachtfan.com/superyacht owners register a h.html while most information about jets came from http://www.refinedguy.com/2012/08/01/15-insanely-expensiveprivate-jets-and-the-billionaires-who-own-them/\#2 and http://www.hollywoodreporter.com/gallery/private-jetsoprah-tom-cruise-spielberg-trump-cuban-bloomberg-368304. Details about other sites are available from the authors. Expensive art ownership is measured by being on the Top 200 art collectors in 2013 of Artnews http://www.artnews.com/2013/07/09/the-2013-artnews-200-top-collectors/
}

27 Tables available in the online appendix AO5. 
More importantly, we also find that the charitable behavior of billionaires is linked to the source of their wealth. Compared to billionaires who inherited their wealth, self-made billionaires are three to four times more likely to sign the Giving Pledge or to be present in the Philanthropy Top 50 list of biggest pledges. Self-made billionaires are also 28 percent more likely to be present in the Million Dollar List, a list of those who have given grants of 1 million or more since 2000. We also find that, conditional on giving, self-made billionaires tend to give more than billionaires who have inherited their fortunes.

We show that these differences between inherited and self-made billionaires are unlikely to be driven by differences in demographic characteristics or by differences in the networks of inherited and self-made billionaires. We do find some evidence that more is known about selfmade billionaires (at least, Forbes knows more about them) and that self-made billionaires are more inclined towards very big ticket items consumption. Our results are thus consistent with the anecdotic evidence that many self-made billionaires prefer not to leave too much money to their children while those billionaires who have inherited money feel an obligation to also leave money to their children.

If the generosity of billionaires is indeed linked to how they acquired their wealth, there are several policy implications. First, policies that will change the relative balance of inherited versus self-made billionaires will then have an impact on charitable giving in a country. There is some evidence that there are more (self-made) billionaires in countries where private property is supported and market-enhancing institutions exist (Leeson and Sanandaji, 2013). This suggest that laws that reduce the importance of private property and/or the functioning of markets will, by hampering new entrepreneurial billionaires to emerge, reduce the occurrence of major charitable gifts.

Second, if self-made billionaires are indeed more generous, the timing of policies that aim to create a charity-friendly environment matters. A recent small survey by Milner (2012) confirms that many emerging markets have lots of room for regulatory improvement in terms of how they treat charity.

Finally, if self-made billionaires are more generous because they do not want to spoil their children by bequeathing them with too much money, while those who have inherited money themselves want to pass this inheritance on to their children, then policy interventions that affect the relative ease of charitable giving (like those affecting bequests) will affect many 
generations. They will both affect the charitable giving of current billionaires, but also through the transmission of values affect the giving of their offspring.

\section{References}

Andreoni, James (2006), "Philanthropy", chapter 18 in "Handbook of Giving, Reciprocity and Altruism" edited by L.-A. Gerard-Varet, Serge-Christophe Kolm and Jean Mercier Ythier, p. 1201-1269

Arkes, H.R., Joyner,C. A., Pezzo, M. V., Nash, J. G., Siegel-Jacobs, K., \& Stone,E. (1994), "The psychology of windfall gains". Organizational Behavior and Human Decision Processes, 59, 331-347.

Arrondel, Luc, Andre Masson and Pierre Pestieau (1997), "Bequests and inheritance: empirical issues and France-U.S. comparison", chapter 4 in "Is Inheritance Legitimate ? Ethical and Economic Aspects of Wealth Transfers" edited by G.Erreygers et T. Vandevelde, pp. 89-125, Springer-Verlag, Berlin.

Epley Nicholas, Dennis Mak and Lorraine Chen Idson (2006), "Bonus of Rebate?: The Impact of Income Framing on Spending and Saving", Journal of Behavioral Decision Making, vol. 19, p. 213-227 (2006)

Havens, John J., Paul G. Schervish, and Mary A. O'Herlihy (2006), "Charitable Giving: How Much, By Whom, To What, and How", in The Nonprofit Sector: A Research Handbook, Second Edition. Walter W. Powell and Richard Steinberg (eds.) Yale University Press.

Leeson, Peter and Tino Sanandaji, 2013, "Billionaires", Industrial and Corporate Change, vol. 22(1), p. 313-337

Kaplan, Steven N. and Joshua Rauh (2013), "It's the Market: The Broad-Based Rise in the Return to Top Talent", Journal of Economic Perspectives-Volume 27, Number 3-Summer 2013-Pages 35-56

King, Gary, and Langche Zeng. 2001. "Logistic Regression in Rare Events Data", Political Analysis 9: 137-163

Kopczuk, Wojciech (2013), "Taxation of Intergenerational Transfers and Wealth" in Alan Auerbach, Raj Chetty, Martin Feldstein and Emmanuel Saez (eds.), Handbook of Public Economics, volume V, 2013, Elsevier, 329-90.

Loomis, Carol (2010), "The $\$ 600$ billion challenge", Forbes http://features.blogs.fortune.cnn.com/2010/06/16/gates-buffett-600-billion-Dollarphilanthropy-challenge/

Miller , Claire Cain (2013), "Laurene Powell Jobs and Anonymous Giving in Silicon Valley", New York Times, May 24, 2013 
Milner, Andrew (2012), "Philanthropic Infrastructure In Emerging Markets", http://www.alliancemagazine.org/members/pdfs/ReportonBuildingBridgesmeetinginLondon,23-

24January2012.pdf

Neumayer, Eric (2004), "The super-rich in global perspective: a quantitative analysis of the Forbes list of billionaires", Applied Economics Letters, 11 (13), 2004, pp. 793-796.

Ostrower, Francie (1995), "Why the Wealthy Give: The Culture of Elite Philanthropy", Princeton, NJ: Princeton University Press.

Peacey Mike W. and Michael Sanders (2012), "Masked Heroes: endogenous anonymity in charitable giving", working paper

Reinstein, David and Gerhard Riener (2012), "Decomposing desert and tangibility effects in a charitable giving experiment”, Experimental Economics, Volume 15, issue 1 (March 2012), p. $229-240$

Roberts, Roxanne (2014), "Why the super-rich aren't leaving much of their fortunes to their kids", Washington Post, August 10, 2014

Steinberg, Richard, Mark Wilhelm, Patrick Rooney, and Eleanor Brown (2011), "Earned, Owned, or Transferred: Are Donations Sensitive to the Composition of Income", working paper

Thakur Pooja, April Lee and Andrew Frye (2011), "Gates Says Self-Made Wealthy Are More Generous Than Heirs", Bloomberg.com, March 24, 2011, http://www.bloomberg.com/news/2011-03-24/bill-gates-says-self-made-wealthy-are-moregenerous-than-heirs.html

United for a Fair Economy (2012), "Born On Third Base: What the Forbes 400 Really Says About Economic Equality and in America", http://faireconomy.org/sites/default/files/BornOnThirdBase2012.pdf

Wilhelm, Mark, Eleanor Brown, Patrick Rooney and Richard Steinberg (2008), "The Intergenerational Transmission of Generosity," Journal of Public Economics, vol. 92 (10-11), p. $2145-2156$ 


\section{Tables}

Table 1 - Charity by origin of wealth

\begin{tabular}{|c|c|c|c|c|c|}
\hline & $\begin{array}{c}\text { Self- } \\
\text { made (1) }\end{array}$ & $\begin{array}{l}\text { Inherite } \\
d(2)\end{array}$ & $\begin{array}{l}\text { difference } \\
\text { (1)-(2) }\end{array}$ & $\begin{array}{l}\text { Stand. Error diff. } \\
\text { (1)-(2) }\end{array}$ & $\begin{array}{l}\text { Ratio } \\
(1) /(2)\end{array}$ \\
\hline Signed Giving Pledge (\%) & 7.8 & 2.1 & 5.7 & 1.3 & 3.65 \\
\hline $\begin{array}{l}\text { Signed Giving Pledge (US) (\%) } \\
\text { In Philanthropy Top } 50 \text { (US) }\end{array}$ & 20.8 & 4.7 & 16.1 & 3.8 & 4.46 \\
\hline (\%) & 26.2 & 9.3 & 16.9 & 4.2 & 2.81 \\
\hline $\begin{array}{l}\text { In Million Dollar List (US) (\%) } \\
\text { Phil. Top } 50 \text { (mean, million }\end{array}$ & 61.7 & 48.1 & 13.6 & 5.1 & 1.28 \\
\hline $\begin{array}{l}\text { US\$) } \\
\text { Million Dollar List (mean, }\end{array}$ & 273 & 15.9 & 257 & 241 & 17.2 \\
\hline $\begin{array}{l}\text { million US\$) } \\
\text { Phil. Top } 50 \text { (median, million }\end{array}$ & 306 & 27 & 279 & 247 & 11.3 \\
\hline $\begin{array}{l}\text { US\$) } \\
\text { Million Dollar List (median, } \\
\text { million USS) }\end{array}$ & 0 & 0 & & & \\
\hline $\begin{array}{l}\text { Phil. Top } 50 \text { (mean if >0, } \\
\text { million US\$) }\end{array}$ & 1000 & 107 & 893 & 1530 & 9.34 \\
\hline $\begin{array}{l}\text { Million Dollar List (mean if }>0 \text {, } \\
\text { million US\$) } \\
\text { Phil. Top } 50 \text { (median, million }\end{array}$ & 497 & 56 & 441 & 453 & 8.87 \\
\hline $\begin{array}{l}\text { US\$) } \\
\text { Million Dollar List (median, } \\
\text { million US\$) }\end{array}$ & 104 & 47 & & & \\
\hline
\end{tabular}

The standard error in Column 4 is the standard error of the difference in column 3. 
Table 2 - Descriptive Statistics for the sample of U.S. billionaires

\begin{tabular}{|c|c|c|c|c|c|}
\hline Variable & Obs & Mean & Std. Dev. & Min & $\operatorname{Max}$ \\
\hline Pledged (dummy 0 or 1 ) & 442 & 0.16 & 0.37 & 0 & 1 \\
\hline Self - made (dummy 0 or 1 ) & 442 & 0.71 & 0.46 & 0 & 1 \\
\hline Net Worth (billions US \$) & 442 & 4.24 & 6.45 & 1 & 67 \\
\hline Connections (\#) & 442 & 4.20 & 7.17 & 0 & 35 \\
\hline Age (years) & 442 & 66.1 & 12.92 & 28 & 97 \\
\hline Family Wealth $\%$ (dummy 0 or 1 ) & 442 & 0.05 & 0.23 & 0 & 1 \\
\hline In a Relationship (dummy 0 or 1 ) & 442 & 0.80 & 0.40 & 0 & 1 \\
\hline Missing Relation (dummy 0 or 1 ) & 442 & 0.00 & 0.07 & 0 & 1 \\
\hline One Child (dummy 0 or 1 ) & 442 & 0.05 & 0.22 & 0 & 1 \\
\hline Two Children (dummy 0 or 1 ) & 442 & 0.25 & 0.44 & 0 & 1 \\
\hline Three Children (dummy 0 or 1 ) & 442 & 0.31 & 0.46 & 0 & 1 \\
\hline 4 or more Children (dummy 0 or 1 ) & 442 & 0.31 & 0.46 & 0 & 1 \\
\hline Missing Education (dummy 0 or 1 ) & 442 & 0.04 & 0.19 & 0 & 1 \\
\hline BA (dummy 0 or 1 ) & 442 & 0.41 & 0.49 & 0 & 1 \\
\hline $\mathrm{M}(\mathrm{B}) \mathrm{A}$ (dummy 0 or 1 ) & 442 & 0.25 & 0.43 & 0 & 1 \\
\hline Doctorate (dummy 0 or 1 ) & 442 & 0.14 & 0.35 & 0 & 1 \\
\hline Business \& Finance \& Diversified & 442 & 0.26 & 0.44 & 0 & 1 \\
\hline Fashion \& Retail \& Food & 442 & 0.16 & 0.37 & 0 & 1 \\
\hline $\begin{array}{c}\text { Automotive, Manufacturing, } \\
\text { Construction/Engineering \& Real Estate }\end{array}$ & 442 & 0.12 & 0.33 & 0 & 1 \\
\hline Media & 442 & 0.08 & 0.27 & 0 & 1 \\
\hline Telecom \& Technology & 442 & 0.12 & 0.33 & 0 & 1 \\
\hline Services & 442 & 0.16 & 0.37 & 0 & 1 \\
\hline Energy \& Oil \& Metals and Mining & 442 & 0.09 & 0.29 & 0 & 1 \\
\hline
\end{tabular}

Omitted categories are 'Single', 'no children', 'High School'. All industry variables are dummy-variables taking values of either 0 or 1. 
Table 3 - Regressing charitable behaviour on origin of wealth and control variables

\begin{tabular}{|c|c|c|c|c|c|}
\hline & \multicolumn{3}{|c|}{ Logit } & \multicolumn{2}{|c|}{ Tobit } \\
\hline & $\begin{array}{c}\text { GP } \\
(1 / 0)\end{array}$ & $\begin{array}{c}\text { Top50 } \\
(1 / 0)\end{array}$ & $\begin{array}{c}\text { Mil. \$ } \\
(1 / 0)\end{array}$ & $\begin{array}{c}\text { Top50 } \\
\text { (Amount) }\end{array}$ & $\begin{array}{c}\text { Mil. \$ } \\
\text { (Amount) }\end{array}$ \\
\hline \multirow[t]{2}{*}{ Self-made } & $0.188 * * *$ & $0.191 * * *$ & 0.065 & $1.849 * * *$ & $0.745^{* *}$ \\
\hline & 0.057 & 0.052 & 0.049 & 0.501 & 0.356 \\
\hline \multirow[t]{2}{*}{ \# Connections } & $0.005 * *$ & $0.008 * * *$ & $0.015 * * *$ & $0.086^{* * *}$ & $0.081 * * *$ \\
\hline & 0.002 & 0.002 & 0.004 & 0.023 & 0.021 \\
\hline \multirow[t]{2}{*}{ Net Worth } & $0.004 *$ & $0.010 * * *$ & $0.015 * * *$ & $0.126 * * *$ & $0.122 * * *$ \\
\hline & 0.002 & 0.003 & 0.005 & 0.022 & 0.022 \\
\hline \multirow[t]{2}{*}{ Age } & 0.002 & $0.006 * * *$ & $0.010 * * *$ & $0.057 * * *$ & $0.095 * * *$ \\
\hline & 0.001 & 0.002 & 0.002 & 0.016 & 0.013 \\
\hline \multirow[t]{2}{*}{ Family Wealth } & -0.132 & -0.000 & 0.007 & -0.959 & -0.191 \\
\hline & 0.129 & 0.085 & 0.095 & 0.954 & 0.674 \\
\hline \multirow[t]{2}{*}{ In a Relationship } & -0.040 & -0.034 & -0.012 & -0.560 & 0.008 \\
\hline & 0.045 & 0.047 & 0.055 & 0.453 & 0.393 \\
\hline \multirow[t]{2}{*}{ Missing Children } & & & -0.157 & & \\
\hline & & & 0.190 & & \\
\hline \multirow[t]{2}{*}{1 Child } & -0.048 & -0.179 & -0.021 & $-1.823^{*}$ & -0.850 \\
\hline & 0.096 & 0.113 & 0.124 & 1.065 & 0.945 \\
\hline \multirow[t]{2}{*}{2 Children } & -0.113 & -0.118 & 0.014 & $-1.236^{*}$ & -0.218 \\
\hline & 0.072 & 0.076 & 0.096 & 0.738 & 0.709 \\
\hline \multirow[t]{2}{*}{3 Children } & -0.061 & $-0.163 * *$ & -0.002 & $-1.736^{* *}$ & -0.324 \\
\hline & 0.07 & 0.075 & 0.094 & 0.743 & 0.70 \\
\hline \multirow[t]{2}{*}{4 or more Children } & -0.083 & -0.104 & -0.013 & $-1.265^{*}$ & -0.405 \\
\hline & 0.07 & 0.075 & 0.095 & 0.732 & 0.709 \\
\hline \multirow[t]{2}{*}{ Missing Education } & & -0.077 & $-0.257^{*}$ & -0.724 & $-2.084 *$ \\
\hline & & 0.162 & 0.147 & 1.577 & 1.185 \\
\hline \multirow[t]{2}{*}{ BA } & -0.026 & 0.048 & -0.013 & 0.457 & -0.181 \\
\hline & 0.052 & 0.057 & 0.063 & 0.82 & -0.40 \\
\hline \multirow[t]{2}{*}{$\mathrm{M}(\mathrm{B}) \mathrm{A}$} & 0.027 & $0.105^{*}$ & -0.010 & $1.027 *$ & 0.003 \\
\hline & 0.055 & 0.061 & 0.071 & 0.598 & 0.503 \\
\hline \multirow[t]{2}{*}{ Doctorate } & 0.021 & 0.043 & 0.012 & 0.358 & 0.403 \\
\hline & 0.063 & 0.070 & 0.080 & 0.677 & 0.559 \\
\hline \multirow[t]{2}{*}{ Fashion \& Retail } & -0.018 & -0.028 & $-0.271 * * *$ & -0.191 & $-2.345^{* * *}$ \\
\hline & 0.063 & 0.062 & 0.074 & 0.665 & 0.561 \\
\hline \multirow[t]{2}{*}{ Automotive and Manufacturing } & -0.058 & -0.049 & -0.065 & -0.621 & $-1.039 * *$ \\
\hline & 0.052 & 0.056 & 0.078 & 0.657 & 0.519 \\
\hline \multirow[t]{2}{*}{ Media } & 0.091 & 0.045 & 0.137 & 0.525 & 0.348 \\
\hline & 0.081 & 0.078 & 0.085 & 0.717 & 0.606 \\
\hline \multirow[t]{2}{*}{ Telecom \& Technology } & $0.130 *$ & $0.150 * *$ & 0.100 & $1.659 * * *$ & $1.348 * *$ \\
\hline & 0.068 & 0.070 & 0.072 & 0.574 & 0.521 \\
\hline Services & -0.060 & -0.020 & -0.037 & -0.149 & $-0.917 *$ \\
\hline
\end{tabular}




\begin{tabular}{|cccccc|}
\hline & 0.053 & 0.058 & 0.072 & 0.63 & 0.498 \\
Energy \& Oil \& Metals and Mining & 0.086 & $0.165^{* *}$ & 0.039 & $1.246^{*}$ & 0.601 \\
Constant & 0.081 & 0.084 & 0.085 & 0.679 & 0.596 \\
Sigma Constant & & & $9.537 * * *$ & $7.948^{* * *}$ \\
& & & & 1.477 & 1.183 \\
R Adj sq. & & & & $2.496 * * *$ & $2.789 * * *$ \\
$\mathrm{~N}$ & 0.144 & 0.181 & 0.182 & 0.147 & 0.139 \\
\hline
\end{tabular}

The dependent variable is a dummy that takes one if signed the Giving Pledge (column 1), being present in the Philanthropy Top 50 (column 2), being present in the Million Dollar List (column 3), the natural log of the amount of gifts in U.S. Dollars based on the Philanthropy Top 50 (column 4) and in the Million Dollar gifts list (column 5). Column 1-3 gives marginal effects after Logit. Column 4 and 5 give coefficients of Tobit regressions with non-givers being censored at the lowest amount available in the sample. Marginal effects and coefficients are given in the table, standard errors are under the marginal effects and coefficients, stars reflect significance level $(* 0.1 * *$ $0.05 * * * 0.01$ ). The comparison group consists of billionaires with education below the BA level who have a diversified or business portfolio of activities. The sample only includes U.S. billionaires. The few observations with missing age, children and/or relationship are excluded in the regressions if the corresponding variables predict non-giving perfectly (logit regressions) or are perfectly collinear (tobit regressions). 
Table 4 - Regressing signing the Giving Pledge on origin of wealth and control variables, using data from all billionaires

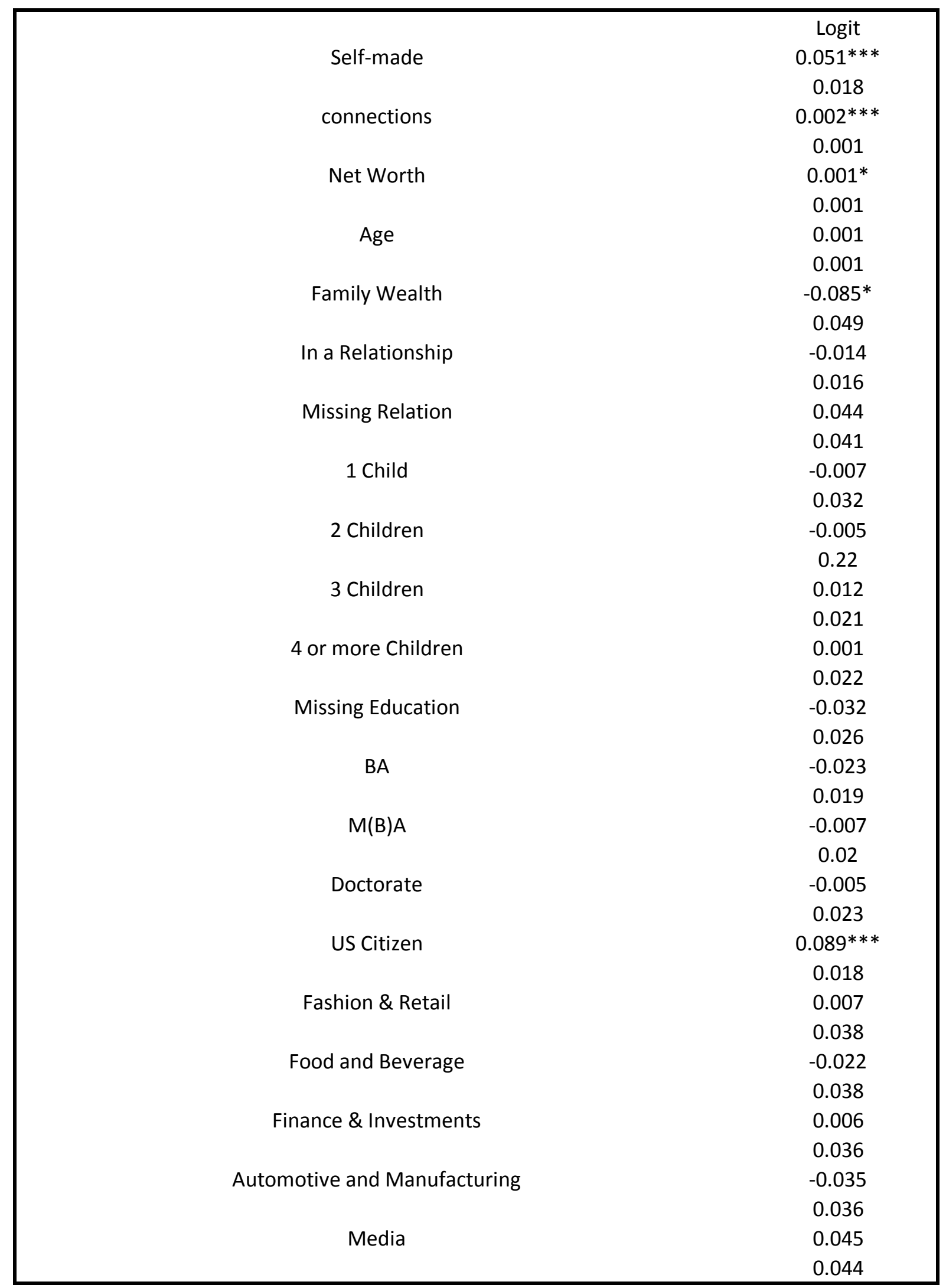




\begin{tabular}{|cc|}
\hline Construction/Engineering \& Real Estate & -0.023 \\
& 0.036 \\
Telecom \& Technology & $0.077^{*}$ \\
& 0.042 \\
Services & -0.023 \\
& 0.035 \\
Energy \& Oil \& Metals and Mining & 0.039 \\
& 0.039 \\
Adjusted/Pseudo R & 0.279 \\
$\mathrm{~N}$ & 1382 \\
\hline
\end{tabular}

The dependent variable is a dummy that is 1 for those having signed the Giving Pledge. Average marginal effects are given in the table, $t$ stats are under the coefficients, stars reflect significance level $(* 0.1 * * 0.05 * * * 0.01)$. The comparison group consists of billionaires with education below the BA level, who have no (reported) children, are not in a relationship, with known age and have a diversified or business portfolio of activities. In column 1 (Logit) and 2 (Probit) missing age predicts (not giving) perfectly and hence these observations are excluded 
Table 5 - Consumption of Very Big Ticket Items by origin of wealth (\%)

\begin{tabular}{|cccccc|}
\hline & $\begin{array}{c}\text { Self-made } \\
(1)\end{array}$ & $\begin{array}{c}\text { Inherited } \\
(2)\end{array}$ & $\begin{array}{c}\text { difference } \\
(1)-(2)\end{array}$ & $\begin{array}{c}\text { standard error of } \\
\text { difference }\end{array}$ & $\begin{array}{c}\text { Ratio } \\
(1) /(2)\end{array}$ \\
Signed Giving Pledge & 7.8 & 2.1 & 5.7 & 1.3 & 3.65 \\
Yachts, Jets or Art & 10 & 7.7 & 2.3 & 1.6 & 1.3 \\
Yachts & 4.9 & 3.6 & 1.3 & 1.2 & 1.33 \\
Jets & 3.3 & 1.3 & 2 & 1 & 2.5 \\
Art & 4.2 & 3.6 & 0.6 & 1 & 1.17 \\
Signed Giving Pledge & & & & & \\
(US only) & 20.8 & 4.7 & 16.1 & 3.8 & 4.47 \\
Yachts, Jets or Art & & & & & \\
(US only) & 17 & 7.7 & 9.3 & 3.7 & 2.2 \\
Yachts (US only) & 6.4 & 3.1 & 3.3 & 2.4 & 2.1 \\
Jets (US only) & 6.4 & 1.5 & 4.9 & 2.3 & 2.1 \\
Art (US only) & 8.0 & 3.9 & 4.1 & 2.6 & \\
\hline
\end{tabular}

The standard error in Column 4 is the standard error of the difference in column 3 . The table give percentages of all billionaires (top) and U.S. billionaires (bottom) 
ONLINE APPENDIX - the Charity of the Extremely Wealthy

Online Appendix OAI- Information about networks of billionaires

We collected information about non-profit memberships of billionaires from the littlesis.org website. Littlesis.org "is a free database detailing the connections between powerful people and organizations" and has detailed information about positions and memberships in non-profit organizations of many billionaires. From Littlesis.org we have information about non-profit positions, in a total of 462 different organizations, for 296 billionaires of the 2013 Forbes list. The other billionaires either do not hold such positions in the organizations covered by Littlesis or are not known to hold such positions. Littlesis.org focuses on membership of U.S.-based organizations so it is not surprising that 241 out of the 296 billionaires included are U.S.-based billionaires. Through "interlocking" memberships, billionaires can be connected to each other.

OAI - Table 1 - Non-profit Memberships by origin of wealth

\begin{tabular}{|c|c|c|c|c|}
\hline & $\begin{array}{c}\text { \% who hold } \\
\text { positions }\end{array}$ & $\begin{array}{c}\text { Mean \# positions if holds } \\
\text { (median) }\end{array}$ & $\begin{array}{c}\text { \% who hold } \\
\text { positions } \\
\text { US only }\end{array}$ & $\begin{array}{c}\text { Mean \# positions if } \\
\text { holds } \\
\text { US only } \\
\text { (median) }\end{array}$ \\
\hline $\begin{array}{c}\text { \% Self Made } \\
(1)\end{array}$ & 0.211 & $\begin{array}{c}\text { (m) } \\
(2)\end{array}$ & $\begin{array}{c}3.52 \\
(2)\end{array}$ \\
\hline $\begin{array}{c}\% \text { Inherited } \\
(2)\end{array}$ & 0.201 & $(1.5)$ & 0.546 & 2.81 \\
\\
Ratio (1)/(2)
\end{tabular}

Shares are in percentages with 0.211 meaning $21.1 \%$.

OAI - Table 2 - Non-profit Network by origin of wealth - all billionaires

\begin{tabular}{|c|c|c|c|c|c|c|}
\hline & $\begin{array}{c}\text { \% connected } \\
\text { (of those } \\
\text { holding a } \\
\text { position) }\end{array}$ & $\begin{array}{c}\text { Mean \# } \\
\text { connections } \\
\text { if connected } \\
\text { (median) }\end{array}$ & \% Self Made & \% Pledge & \% Phil50 & \% Million \$ \\
\hline $\begin{array}{c}\text { \% Self Made } \\
(1)\end{array}$ & 0.83 & $\begin{array}{c}9.1 \\
(6)\end{array}$ & $\begin{array}{c}0.72 \\
(0.75)\end{array}$ & $\begin{array}{c}0.25 \\
(0.21)\end{array}$ & $\begin{array}{c}0.35 \\
(0.33)\end{array}$ & $\begin{array}{c}0.68 \\
(0.74)\end{array}$ \\
\hline $\begin{array}{c}\text { \% Inherited } \\
(2)\end{array}$ & 0.80 & $\begin{array}{c}0.2 \\
(6)\end{array}$ & $\begin{array}{c}0.74 \\
(0.79)\end{array}$ & $\begin{array}{c}0.19) \\
0.33\end{array}$ & $\begin{array}{c}0.67 \\
(0.33)\end{array}$ \\
\hline Ratio (1)/(2) & 1.04 & $\begin{array}{c}1.25 \\
(1)\end{array}$ & $\begin{array}{c}0.97 \\
(0.95)\end{array}$ & $\begin{array}{c}1.28 \\
(1.14)\end{array}$ & $\begin{array}{c}1.06 \\
(1)\end{array}$ & $\begin{array}{c}1.01 \\
(1.03)\end{array}$ \\
\hline
\end{tabular}

Shares are in percentages with 0.83 meaning $83 \%$. 
OAI - Table 3 - Non-profit Network by origin of wealth - U.S. billionaires only

\begin{tabular}{|c|c|c|c|c|c|c|}
\hline & Is connected & $\begin{array}{c}\text { Mean \# } \\
\text { connections } \\
\text { if connected } \\
\text { (median) }\end{array}$ & \% Self Made & \% Pledge & \% Phil50 & \% Million \$ \\
\hline $\begin{array}{c}\text { \% Self Made } \\
(1)\end{array}$ & 0.84 & $\begin{array}{c}8.9 \\
(6)\end{array}$ & $\begin{array}{c}0.74 \\
(0.79)\end{array}$ & $\begin{array}{c}0.25 \\
(0.24)\end{array}$ & $\begin{array}{c}0.37 \\
(0.37)\end{array}$ & $\begin{array}{c}0.76 \\
(0.82)\end{array}$ \\
\hline $\begin{array}{c}\text { \% Inherited } \\
(2)\end{array}$ & 0.77 & $\begin{array}{c}7.5 \\
(7)\end{array}$ & $\begin{array}{c}0.77 \\
(0.81)\end{array}$ & $\begin{array}{c}0.21 \\
(0.18)\end{array}$ & $\begin{array}{c}0.39 \\
(0.36)\end{array}$ & $\begin{array}{c}0.75 \\
(0.8)\end{array}$ \\
\hline Ratio (1)/(2) & 1.09 & $\begin{array}{c}1.19 \\
(0.86)\end{array}$ & $\begin{array}{c}0.96 \\
(0.97)\end{array}$ & $\begin{array}{c}1.2 \\
(1.38)\end{array}$ & $\begin{array}{c}0.94 \\
(1.03)\end{array}$ & $\begin{array}{c}1.01 \\
(1.02)\end{array}$ \\
\hline
\end{tabular}

Shares are in percentages with 0.84 meaning $84 \%$. 
Online Appendix AO2- Explaining Missing Information

Missing info is 1 if Forbes misses information about age, education or relationship status for a given billionaire, zero otherwise.

\begin{tabular}{|c|c|c|}
\hline & \multicolumn{2}{|c|}{ Logit } \\
\hline & Missing Info (all billionaires) (1/0) & Missing Info (U.S. billionaires) (1/0) \\
\hline Self-made & $-0.081^{* * *}$ & $-0.048^{* *}$ \\
\hline & -3.49 & -1.97 \\
\hline Net Worth & $-0.006^{* *}$ & -0.004 \\
\hline & -2.34 & -1.42 \\
\hline US Citizen & $-0.417^{* * *}$ & \\
\hline & -14.27 & $0.105^{* * *}$ \\
\hline Family Wealth & 0.040 & 2.95 \\
\hline & 1.28 & $-0.140^{* *}$ \\
\hline 1 Child & $-0.256^{* * *}$ & -2.19 \\
\hline & -6.04 & $-0.100^{* * *}$ \\
\hline 2 Children & $-0.175^{* * *}$ & -2.90 \\
\hline & -5.43 & $-0.096^{* * *}$ \\
\hline 3 Children & $-0.193^{* * *}$ & -2.81 \\
\hline & -5.92 & $-0.086^{* * *}$ \\
\hline 4 or more Children & $-0.134^{* * *}$ & -2.73 \\
\hline & -4.07 & YES \\
\hline Industry Dummies & YES & 0.229 \\
\hline R Adj sq. & 0.221 & 442 \\
\hline $\mathrm{N}$ & 1426 & \\
\hline
\end{tabular}

The dependent variable is a dummy that is 1 for those having some information missing (on age, relationship status or education) in the Forbes database. Average marginal effects after a Logit regression are given in the table, $t$ stats are under the coefficients, stars reflect significance level $(* 0.1 * * 0.05 * * * 0.01)$. The comparison group consists of billionaires who have no (reported) children and have a diversified or business portfolio of activities. The variables related to age, relationship status and education are excluded as explanatory variables as they would perfectly predict the dependent variable. Industry Dummies are included in both regressions (10 industries for the regression with all billionaires, 7 industries if only U.S. billionaires are included). 
Online Appendix OA3: Year-by-Year analysis, 167 U.S. billionaires present between 2001 and 2013

As a robustness check, we created a dataset of all billionaires in the Forbes 400 between 2000 and 2013, with information about their net worth for each year. Unfortunately, the demographic information is no longer available for earlier years so we use the 2013 information.

We matched this yearly data to the yearly gifts data from the Philanthropy top 50 and the Million Dollar List (up to 2012 for the Top 50, up to 2013 for the Million Dollar List).

Below are the results of regressions using billionaires who have been billionaires in both 2001 and 2013 (in 2000 there were very few billionaires given the recession) and hence have had a reasonable stable net wealth. An observation is a given billionaire present in a given year. Standard errors are clustered at the level of the individual billionaire.

All regressions show sizeable positive coefficients of the self-made dummy.

Column 1 gives the results of a logit, using presence in the Philanthropy top 50 as dependent variable. Column 2 gives the average marginal effects after a logit, using presence in the Million Dollar list as dependent variable.

Column 3-5 focus on the natural log of the amount of money given in a given year, as indicated when a person is part of the Philanthropy top 50, with values assumed to be censored at the lowest level needed to enter the top 50. Column 3 gives the coefficients of an OLS regression, Column 4 the coefficients of a Tobit regression and column 5 the marginal effects, based on the Tobit regression of column 4, reflecting marginal effects on the censored data (hence comparable to the OLS regression).

Column 6-8 focus on the natural log of the amount of money given in a given year, based on the Million Dollar list gifts, with values assumed to be censored at 1 million dollar. Column 6 gives the coefficients of an OLS regression, Column 7 the coefficients of a Tobit regression and column 8 the marginal effects, based on the Tobit regression of column 4, reflecting marginal effects on the censored data (hence comparable to the OLS regression).

OA3 - regression analysis using 167 U.S. billionaires present between 2001 and 2013

\begin{tabular}{|c|c|c|c|c|c|c|c|c|}
\hline & Logit & Logit & OLS & Tobit & Tobit ME & OLS & Tobit & Tobit ME \\
\hline & Top 50 & Million \$ & Top 50 & Top 50 & Top 50 & Million \$ & Million \$ & Million \$ \\
\hline Self-made & $0.086^{* *}$ & 0.083 & $0.137 * * *$ & $3.195^{* * *}$ & $0.186 * *$ & $0.417 * * *$ & $1.322^{* * *}$ & $0.422^{* * *}$ \\
\hline & 2.06 & 1.62 & 2.69 & 2.66 & 2.47 & 3.21 & 2.96 & 2.84 \\
\hline connections & 0.002 & 0.002 & $0.014 * *$ & $0.117 * * *$ & $0.007 * * *$ & $0.021^{*}$ & 0.031 & 0.01 \\
\hline & 1.36 & 0.74 & 2.05 & 3 & 2.62 & 1.66 & 1.18 & 1.18 \\
\hline Net Worth & $0.003^{* * *}$ & $0.007 * *$ & $0.029 * * *$ & $0.152^{* * *}$ & $0.009 * * *$ & $0.060^{* * *}$ & $0.104 * * *$ & $0.033^{* * *}$ \\
\hline & 2.97 & 2.15 & 3.17 & 4.46 & 3.5 & 3.09 & 3.71 & 3.57 \\
\hline Age & 0 & $0.007 * * *$ & 0.003 & 0.042 & 0.002 & $0.019 * *$ & $0.069^{* * *}$ & $0.022^{* * *}$ \\
\hline & 0.24 & 3.47 & 1.04 & 1.26 & 1.22 & 2.41 & 3.34 & 3.3 \\
\hline
\end{tabular}




\begin{tabular}{|c|c|c|c|c|c|c|c|c|}
\hline Family Wealth & $-0.071 * *$ & -0.141 & -0.024 & $-1.779 *$ & -0.104 & -0.25 & -0.958 & -0.306 \\
\hline & -2.03 & -1.55 & -0.51 & -1.74 & -1.61 & -1.22 & -1.21 & -1.2 \\
\hline \multirow[t]{2}{*}{$\begin{array}{c}\text { In a } \\
\text { Relationship } \\
\end{array}$} & $-0.068 * *$ & 0.009 & 0.005 & -0.18 & -0.01 & 0.072 & 0.32 & 0.102 \\
\hline & -2.53 & 0.18 & 0.08 & -0.25 & -0.25 & 0.45 & 0.73 & 0.72 \\
\hline \multirow[t]{2}{*}{1 Child } & -0.067 & -0.047 & 0.006 & -2.423 & -0.141 & -0.04 & -1.15 & -0.367 \\
\hline & -1.07 & -0.31 & 0.05 & -1.22 & -1.2 & -0.13 & -0.96 & -0.96 \\
\hline \multirow[t]{2}{*}{2 Children } & -0.011 & 0.101 & 0.004 & -1.156 & -0.067 & 0.332 & 0.832 & 0.266 \\
\hline & -0.27 & 1.2 & 0.03 & -0.95 & -0.97 & 1.3 & 1.13 & 1.12 \\
\hline \multirow[t]{2}{*}{3 Children } & $-0.085^{*}$ & 0.025 & -0.088 & $-2.858 * *$ & $-0.167 * *$ & 0.05 & 0.042 & 0.013 \\
\hline & -1.89 & 0.3 & -0.79 & -2.09 & -2 & 0.19 & 0.06 & 0.06 \\
\hline \multirow[t]{2}{*}{$\begin{array}{l}4 \text { or more } \\
\text { Children }\end{array}$} & -0.05 & 0.087 & -0.065 & -2.052 & -0.12 & 0.11 & 0.303 & 0.097 \\
\hline & -1.21 & 1.03 & -0.55 & -1.58 & -1.5 & 0.41 & 0.4 & 0.4 \\
\hline \multirow[t]{2}{*}{$\mathrm{BA}$} & 0.013 & -0.097 & 0.011 & 0.703 & 0.041 & -0.154 & -0.516 & -0.165 \\
\hline & 0.4 & -1.64 & 0.15 & 0.74 & 0.71 & -0.78 & -0.93 & -0.94 \\
\hline \multirow[t]{2}{*}{$\mathrm{M}(\mathrm{B}) \mathrm{A}$} & 0.036 & $-0.185^{* * *}$ & -0.058 & 0.342 & 0.02 & $-0.424 *$ & $-1.268 *$ & $-0.405^{*}$ \\
\hline & 1.02 & -2.77 & -0.59 & 0.29 & 0.29 & -1.76 & -1.95 & -1.94 \\
\hline \multirow[t]{2}{*}{ Doctorate } & -0.002 & -0.085 & -0.032 & 0.982 & 0.057 & -0.197 & -0.514 & -0.164 \\
\hline & -0.06 & -0.98 & -0.33 & 0.81 & 0.79 & -0.66 & -0.71 & -0.71 \\
\hline \multirow[t]{2}{*}{$\begin{array}{c}\text { Fashion \& } \\
\text { Retail } \\
\end{array}$} & -0.033 & $-0.299 * * *$ & $-0.164 * *$ & $-2.580 * *$ & $-0.103 * *$ & $-0.536 * *$ & $-2.109 * * *$ & $-0.608 * * *$ \\
\hline & -0.84 & -4.53 & -2.22 & -2.13 & -2.24 & -2.55 & -2.8 & -3.23 \\
\hline \multirow[t]{2}{*}{$\begin{array}{c}\text { Automotive and } \\
\text { Manufacturing }\end{array}$} & $-0.071 * * *$ & $-0.219 * * *$ & $-0.164 *$ & $-3.430 * * *$ & $-0.116^{* * * *}$ & $-0.547 * * *$ & $-1.789 * * *$ & $-0.543 * * *$ \\
\hline & -2.99 & -2.77 & -1.89 & -3.39 & -2.89 & -2.94 & -2.6 & -2.93 \\
\hline \multirow[t]{2}{*}{ Media } & -0.041 & $-0.184 * *$ & -0.115 & $-2.150^{* *}$ & $-0.094 * *$ & $-0.378 *$ & $-1.228 *$ & $-0.407 * *$ \\
\hline & -1.34 & -2.52 & -1.59 & -2.22 & -2.12 & -1.76 & -1.86 & -1.99 \\
\hline \multirow[t]{2}{*}{$\begin{array}{c}\text { Telecom \& } \\
\text { Technology } \\
\end{array}$} & 0.069 & -0.001 & 0.064 & 0.886 & 0.075 & 0.351 & 0.542 & 0.232 \\
\hline & 1.58 & -0.01 & 0.6 & 0.99 & 0.92 & 1.1 & 0.8 & 0.77 \\
\hline \multirow[t]{2}{*}{ Services } & 0.007 & $-0.180^{* * *}$ & 0 & 0.126 & 0.009 & -0.23 & $-1.137 *$ & $-0.382 *$ \\
\hline & 0.17 & -2.66 & 0 & 0.1 & 0.1 & -1.05 & -1.75 & -1.84 \\
\hline \multirow[t]{2}{*}{$\begin{array}{c}\text { Energy \& Oil \& } \\
\text { Metals and } \\
\text { Mining } \\
\end{array}$} & 0.013 & 0.047 & -0.047 & 0.773 & 0.064 & 0.145 & 0.711 & 0.312 \\
\hline & 0.26 & 0.53 & -0.48 & 0.58 & 0.54 & 0.55 & 1.09 & 1.04 \\
\hline Year Dummies & Yes & Yes & Yes & Yes & Yes & Yes & Yes & Yes \\
\hline \multirow[t]{2}{*}{ Constant } & & & $16.181^{* * * *}$ & 5.099 ** & & $12.706^{* * *}$ & $6.596^{* * * *}$ & \\
\hline & & & 77.57 & 2.04 & & 20.35 & 3.94 & \\
\hline \multicolumn{9}{|l|}{ Sigma } \\
\hline & & & & $3.491 * * *$ & & & $2.939 * * *$ & \\
\hline & & & & 9.47 & & & 19.92 & \\
\hline $\begin{array}{c}\text { Adjusted/Pseudo } \\
\text { R2 }\end{array}$ & 0.21 & 0.166 & & 0.196 & 0.196 & & 0.105 & 0.105 \\
\hline $\mathrm{N}$ & 1906 & 2073 & 1734 & 1734 & 1734 & 2073 & 2073 & 2073 \\
\hline
\end{tabular}

T stats are under the coefficients, stars reflect significance level $(* 0.1 * * 0.05 * * * 0.01)$. The meaning of the columns are described above. 
One could argue that above regression is subject to sample selection bias - some billionaires could no longer be billionaires because they gave away their fortune. While this happens, browsing through the Forbes' billionaires drop-off list suggests dropping off the billionaire list because of charity is rare - we found three cases, all self-made billionaires, who at some point dropped off the Forbes list possibly because of their charitable activities: Chuck Feeney $^{28}$, J.K. Rowling ${ }^{29}$ and Olav Thon ${ }^{30}$.

\footnotetext{
${ }^{28}$ http://www.forbes.com/sites/danalexander/2014/06/18/warren-buffett-honors-his-hero-the-billionairewho-secretly-gave-it-all-away/

${ }^{29}$ http://www.forbes.com/sites/freddreier/2012/03/07/billionaire-dropoffs/

${ }^{30}$ http://www.forbes.com/sites/danalexander/2014/03/04/fumbled-fortunes-meet-the-ex-billionaires-wholost-their-riches/
} 
Online Appendix OA4 - Regression Analysis of the Giving Pledge using all billionaires

OA4 - Descriptive Statistics for the Variables Used in the Logit Regressions of table 4 in the paper.

\begin{tabular}{|c|c|c|c|c|c|}
\hline Variable & Obs & Mean & Std. Dev. & Min & Max \\
\hline Pledged (dummy 0 or 1 ) & 1382 & 0.06 & 0.24 & 0 & 1 \\
\hline Self - made (dummy 0 or 1 ) & 1382 & 0.69 & 0.46 & 0 & 1 \\
\hline Net Worth (billions US \$) & 1382 & 3.81 & 5.43 & 1 & 73 \\
\hline Age (years) & 1382 & 63.00 & 13.11 & 28 & 97 \\
\hline US Citizen $\%$ (dummy 0 or 1$)$ & 1382 & 0.32 & 0.47 & 0 & 1 \\
\hline Family Wealth $\%$ (dummy 0 or 1$)$ & 1382 & 0.12 & 0.32 & 0 & 1 \\
\hline In a Relationship (dummy 0 or 1 ) & 1382 & 0.80 & 0.40 & 0 & 1 \\
\hline Missing Relation (dummy 0 or 1 ) & 1382 & 0.05 & 0.21 & 0 & 1 \\
\hline One Child (dummy 0 or 1 ) & 1382 & 0.09 & 0.29 & 0 & 1 \\
\hline Two Children (dummy 0 or 1 ) & 1382 & 0.24 & 0.43 & 0 & 1 \\
\hline Three Children (dummy 0 or 1 ) & 1382 & 0.25 & 0.43 & 0 & 1 \\
\hline 4 or more Children (dummy 0 or 1 ) & 1382 & 0.25 & 0.44 & 0 & 1 \\
\hline Missing Education (dummy 0 or 1 ) & 1382 & 0.35 & 0.48 & 0 & 1 \\
\hline BA (dummy 0 or 1$)$ & 1382 & 0.31 & 0.46 & 0 & 1 \\
\hline $\mathrm{M}(\mathrm{B}) \mathrm{A}$ (dummy 0 or 1 ) & 1382 & 0.19 & 0.39 & 0 & 1 \\
\hline Doctorate (dummy 0 or 1 ) & 1382 & 0.08 & 0.27 & 0 & 1 \\
\hline Fashion \& Retail & 1382 & 0.12 & 0.32 & 0 & 1 \\
\hline Food and Beverage & 1382 & 0.07 & 0.25 & 0 & 1 \\
\hline Finance \& Investments & 1382 & 0.16 & 0.37 & 0 & 1 \\
\hline Automotive and Manufacturing & 1382 & 0.08 & 0.27 & 0 & 1 \\
\hline Media & 1382 & 0.05 & 0.22 & 0 & 1 \\
\hline Construction/Engineering \& Real Estate & 1382 & 0.12 & 0.33 & 0 & 1 \\
\hline Telecom \& Technology & 1382 & 0.08 & 0.27 & 0 & 1 \\
\hline Services & 1382 & 0.12 & 0.33 & 0 & 1 \\
\hline Energy \& Oil \& Metals and Mining & 1382 & 0.11 & 0.31 & 0 & 1 \\
\hline
\end{tabular}

Omitted categories are 'Single', 'no children or unknown number of children', 'High School' and 'diversified business'. All industry variables are dummy-variables taking values of either 0 or 1 . 
Online Appendix 5 - Robustness Checks

Table 1 gives marginal effects after logit regressions using the three indicators of giving as dependent variables. Column 1-3 include an indicator for being part of the network of Bill Gates and Warren Buffet as an extra variable. Column 4-6 split up the connections variable into connections to self-made billionaires and connections to inherited billionaires. Column 7-9 splits up the connections variable into connections who gave and who did not give. None of these variations affect our conclusions concerning the self-made dummy, however.

OA5 - Table 1 - different proxies for connections

\begin{tabular}{|c|c|c|c|c|c|c|c|c|c|}
\hline & \multicolumn{9}{|c|}{ Logit Regressions (all dependent variables are dummies) } \\
\hline & GP & Top 50 & $\begin{array}{c}\text { Million } \\
\$\end{array}$ & GP & Top 50 & $\begin{array}{c}\text { Million } \\
\$\end{array}$ & GP & Top 50 & $\begin{array}{c}\text { Million } \\
\$\end{array}$ \\
\hline \multirow[t]{2}{*}{ Self-made } & $\begin{array}{c}0.188^{* *} \\
*\end{array}$ & $\begin{array}{c}0.187 * * \\
*\end{array}$ & 0.062 & $\begin{array}{c}0.188^{* *} \\
*\end{array}$ & $\begin{array}{c}0.191^{* *} \\
*\end{array}$ & 0.065 & $\begin{array}{c}0.189^{* *} \\
*\end{array}$ & $\begin{array}{c}0.188^{* *} \\
*\end{array}$ & 0.061 \\
\hline & 3.26 & 3.6 & 1.27 & 3.26 & 3.66 & 1.34 & 3.31 & 3.61 & 1.25 \\
\hline \multirow[t]{2}{*}{ \# Connections } & $0.005^{* *}$ & $\begin{array}{c}0.009^{* *} \\
*\end{array}$ & $\begin{array}{c}0.017^{* *} \\
*\end{array}$ & & & & & & \\
\hline & 2.29 & 3.73 & 4.3 & & & & & & \\
\hline \multirow[t]{2}{*}{ Bill Gates/Warren Buffett } & -0.017 & -0.132 & $0.230^{-}$ & & & & & & \\
\hline & -0.25 & -1.61 & -2.11 & & & & & & \\
\hline \multirow[t]{2}{*}{ Net Worth } & $0.005^{*}$ & $\begin{array}{c}0.011 \text { ** } \\
*\end{array}$ & $\begin{array}{c}0.016^{* *} \\
*\end{array}$ & $0.004 *$ & $\begin{array}{c}0.010^{* *} \\
*\end{array}$ & $\begin{array}{c}0.015^{* *} \\
*\end{array}$ & $0.005^{*}$ & $\begin{array}{c}0.010^{* *} \\
*\end{array}$ & $\begin{array}{c}0.015^{* *} \\
*\end{array}$ \\
\hline & 1.85 & 3.73 & 3.19 & 1.84 & 3.49 & 2.93 & 1.92 & 3.52 & 2.96 \\
\hline \multirow[t]{2}{*}{ Age } & 0.002 & $\begin{array}{c}0.005^{* *} \\
*\end{array}$ & $\begin{array}{c}0.010^{* *} \\
*\end{array}$ & 0.002 & $\begin{array}{c}0.006^{* *} \\
*\end{array}$ & $\begin{array}{c}0.010^{* *} \\
*\end{array}$ & 0.002 & $\begin{array}{c}0.006^{* * *} \\
*\end{array}$ & $\begin{array}{c}0.009^{* *} \\
*\end{array}$ \\
\hline & 1.33 & 3.54 & 5.76 & 1.39 & 3.51 & 5.79 & 1.36 & 3.62 & 5.58 \\
\hline \multirow[t]{2}{*}{ Family Wealth } & -0.132 & -0.007 & -0.004 & -0.131 & -0.002 & 0.007 & -0.131 & -0.001 & 0.006 \\
\hline & -1.03 & -0.08 & -0.05 & -1.02 & -0.03 & 0.08 & -1.02 & -0.01 & 0.06 \\
\hline \multirow[t]{2}{*}{ In a Relationship } & -0.04 & -0.034 & -0.01 & -0.04 & -0.034 & -0.012 & -0.039 & -0.037 & -0.011 \\
\hline & -0.88 & -0.73 & -0.18 & -0.88 & -0.73 & -0.22 & -0.86 & -0.78 & -0.2 \\
\hline \multirow[t]{2}{*}{ Missing Children } & 0 & 0 & -0.181 & 0 & 0 & -0.156 & 0 & 0 & -0.159 \\
\hline & & & -0.95 & . & . & -0.82 & & & -0.84 \\
\hline \multirow[t]{2}{*}{1 Child } & -0.048 & -0.179 & -0.029 & -0.046 & -0.18 & -0.02 & -0.051 & -0.179 & -0.022 \\
\hline & -0.51 & -1.6 & -0.24 & -0.48 & -1.59 & -0.16 & -0.54 & -1.57 & -0.18 \\
\hline \multirow[t]{2}{*}{2 Children } & -0.115 & $-0.126^{*}$ & -0.002 & -0.114 & -0.118 & 0.014 & -0.114 & -0.116 & 0.012 \\
\hline & -1.58 & -1.66 & -0.02 & -1.57 & -1.55 & 0.14 & -1.58 & -1.53 & 0.13 \\
\hline \multirow[t]{2}{*}{3 Children } & -0.062 & $\begin{array}{c}- \\
0.170^{* *} \\
\end{array}$ & -0.013 & -0.061 & $\begin{array}{c}- \\
0.163^{* *} \\
\end{array}$ & -0.001 & -0.064 & $\begin{array}{c}- \\
0.163^{* *} \\
\end{array}$ & 0.001 \\
\hline & -0.88 & -2.26 & -0.14 & -0.87 & -2.17 & -0.01 & -0.93 & -2.17 & 0.01 \\
\hline \multirow[t]{2}{*}{4 or more Children } & -0.083 & -0.105 & -0.022 & -0.082 & -0.104 & -0.012 & -0.08 & -0.103 & -0.009 \\
\hline & -1.18 & -1.41 & -0.23 & -1.17 & -1.39 & -0.12 & -1.15 & -1.37 & -0.1 \\
\hline \multirow[t]{2}{*}{ Missing Education } & 0 & -0.085 & $-0.270 *$ & 0 & -0.086 & $-0.253 *$ & 0 & -0.101 & $-0.244 *$ \\
\hline & . & -0.52 & -1.82 & . & -0.51 & -1.71 & - & -0.59 & -1.69 \\
\hline \multirow[t]{2}{*}{ BA } & -0.026 & 0.046 & -0.022 & -0.024 & 0.046 & -0.012 & -0.024 & 0.048 & -0.014 \\
\hline & -0.5 & 0.81 & -0.35 & -0.47 & 0.81 & -0.19 & -0.47 & 0.85 & -0.23 \\
\hline \multirow[t]{2}{*}{$\mathrm{M}(\mathrm{B}) \mathrm{A}$} & 0.027 & $0.102 *$ & -0.014 & 0.028 & $0.103 *$ & -0.009 & 0.025 & $0.106^{*}$ & -0.005 \\
\hline & 0.48 & 1.68 & -0.2 & 0.51 & 1.7 & -0.12 & 0.46 & 1.75 & -0.07 \\
\hline
\end{tabular}




\begin{tabular}{|c|c|c|c|c|c|c|c|c|c|}
\hline Doctorate & 0.02 & 0.037 & -0.001 & 0.026 & 0.039 & 0.016 & 0.014 & 0.041 & 0.024 \\
\hline & 0.32 & 0.54 & -0.01 & 0.41 & 0.55 & 0.19 & 0.22 & 0.6 & 0.3 \\
\hline \multirow[t]{2}{*}{ Fashion \& Retail } & -0.017 & -0.027 & $\begin{array}{c}- \\
0.271 * * \\
*\end{array}$ & -0.015 & -0.031 & $\begin{array}{c}- \\
0.268^{* *} \\
*\end{array}$ & -0.022 & -0.037 & $\begin{array}{c}- \\
0.248^{* *} \\
*\end{array}$ \\
\hline & -0.27 & -0.45 & -3.71 & -0.23 & -0.5 & -3.5 & -0.36 & -0.6 & -3.28 \\
\hline \multirow[t]{2}{*}{$\begin{array}{l}\text { Automotive and } \\
\text { Manufacturing } \\
\end{array}$} & -0.057 & -0.043 & -0.053 & -0.058 & -0.049 & -0.064 & -0.055 & -0.048 & -0.06 \\
\hline & -1.1 & -0.77 & -0.68 & -1.13 & -0.88 & -0.83 & -1.05 & -0.85 & -0.77 \\
\hline \multirow[t]{2}{*}{ Media } & 0.091 & 0.046 & 0.137 & 0.09 & 0.045 & 0.138 & 0.087 & 0.041 & $0.145^{*}$ \\
\hline & 1.13 & 0.6 & 1.6 & 1.11 & 0.58 & 1.62 & 1.08 & 0.52 & 1.69 \\
\hline \multirow[t]{2}{*}{ Telecom \& Technology } & $0.136^{*}$ & $0.186^{* *}$ & $0.136^{*}$ & $0.130 *$ & $0.149 * *$ & 0.101 & $0.136^{* *}$ & $0.144^{* *}$ & 0.117 \\
\hline & 1.91 & 2.49 & 1.9 & 1.92 & 2.12 & 1.39 & 1.99 & 2.04 & 1.62 \\
\hline \multirow[t]{2}{*}{ Services } & -0.059 & -0.017 & -0.033 & -0.06 & -0.021 & -0.035 & -0.06 & -0.026 & -0.021 \\
\hline & -1.12 & -0.3 & -0.47 & -1.14 & -0.36 & -0.48 & -1.14 & -0.45 & -0.29 \\
\hline \multirow[t]{2}{*}{$\begin{array}{l}\text { Energy \& Oil \& Metals } \\
\text { and Mining } \\
\end{array}$} & 0.088 & $0.171 * *$ & 0.041 & 0.086 & $0.164 *$ & 0.04 & 0.085 & $0.152 *$ & 0.045 \\
\hline & 1.07 & 2.08 & 0.49 & 1.06 & 1.95 & 0.48 & 1.05 & 1.8 & 0.53 \\
\hline \multirow[t]{2}{*}{$\begin{array}{c}\text { Connections to Inherited } \\
\text { Billionaires } \\
\end{array}$} & & & & -0.001 & 0.012 & 0.011 & & & \\
\hline & & & & -0.04 & 0.89 & 0.61 & & & \\
\hline \multirow[t]{2}{*}{$\begin{array}{c}\text { Connections to Self-made } \\
\text { Billionaires } \\
\end{array}$} & & & & 0.007 & 0.006 & $0.016^{* *}$ & & & \\
\hline & & & & 1.46 & 1.24 & 2.1 & & & \\
\hline \multirow[t]{2}{*}{$\begin{array}{c}\text { Connections to Billionaires } \\
\text { who did not pledge }\end{array}$} & & & & & & & $0.011^{* *}$ & & \\
\hline & & & & & & & 2.09 & & \\
\hline \multirow[t]{2}{*}{$\begin{array}{c}\text { Connections to Billionaires } \\
\text { who did pledge }\end{array}$} & & & & & & & -0.011 & & \\
\hline & & & & & & & -0.79 & & \\
\hline \multirow[t]{2}{*}{$\begin{array}{l}\text { Connections to Billionaires } \\
\text { who did not belong to Top } \\
50 \\
\end{array}$} & & & & & & & & $0.014 * *$ & \\
\hline & & & & & & & & 2.46 & \\
\hline \multirow[t]{2}{*}{$\begin{array}{l}\text { Connections to Billionaires } \\
\text { who did belong to Top } 50\end{array}$} & & & & & & & & -0.005 & \\
\hline & & & & & & & & -0.45 & \\
\hline \multirow[t]{2}{*}{$\begin{array}{c}\text { Connections to Billionaires } \\
\text { who did not gave Million } \\
\text { Dollar Gifts } \\
\end{array}$} & & & & & & & & & -0.014 \\
\hline & & & & & & & & & -0.82 \\
\hline \multirow[t]{2}{*}{$\begin{array}{c}\text { Connections to Billionaires } \\
\text { who gave Million Dollar } \\
\text { Gifts } \\
\end{array}$} & & & & & & & & & $\begin{array}{c}0.027^{* *} \\
*\end{array}$ \\
\hline & & & & & & & & & 3.36 \\
\hline R Adj sq. & 0.144 & 0.187 & 0.189 & 0.145 & 0.181 & 0.182 & 0.148 & 0.184 & 0.187 \\
\hline $\mathrm{N}$ & 419 & 431 & 440 & 419 & 431 & 440 & 419 & 431 & 440 \\
\hline
\end{tabular}

Logit regressions with signing the Giving Pledge (GP), presence in the Philanthropy Top 50 or presence in the Million Dollar list as dependent variable. Average marginal effects are given in the table, $\mathrm{t}$ stats are under the coefficients, stars reflect significance level $(* 0.1 * *$ $0.05 * * * 0.01)$ 
OA5 - Table 2 - billionaires with children only

Restricting the sample to billionaires with children, does not affect our conclusions - there are too few billionaires without children to run a regression with such billionaires only.

\begin{tabular}{|c|c|c|c|}
\hline & \multicolumn{3}{|c|}{ Logit Regressions } \\
\hline & GP $(1 / 0)$ & Top $50(1 / 0)$ & Million $\$(1 / 0)$ \\
\hline \multirow[t]{2}{*}{ Self-made } & $0.206^{* * *}$ & $0.170^{* * * *}$ & 0.046 \\
\hline & 3.47 & 3.31 & 0.92 \\
\hline \multirow[t]{2}{*}{ \# Connections } & $0.005^{* *}$ & $0.008 * * *$ & $0.016 * * *$ \\
\hline & 2.3 & 3.31 & 4.05 \\
\hline \multicolumn{4}{|l|}{ Bill Gates/Warren Buffett } \\
\hline \multirow[t]{2}{*}{ Net Worth } & $0.005^{*}$ & $0.009 * * *$ & $0.015^{* * *}$ \\
\hline & 1.92 & 3.17 & 2.74 \\
\hline \multirow[t]{2}{*}{ Age } & 0.002 & $0.005 * * *$ & $0.009 * * *$ \\
\hline & 1.09 & 2.96 & 4.89 \\
\hline \multirow[t]{2}{*}{ Family Wealth } & -0.112 & 0.003 & 0.003 \\
\hline & -0.91 & 0.04 & 0.03 \\
\hline \multirow[t]{2}{*}{ In a Relationship } & -0.045 & -0.047 & 0.009 \\
\hline & -0.95 & -0.95 & 0.16 \\
\hline Missing Children & 0 & 0 & $\underline{0}$ \\
\hline \multirow[t]{2}{*}{1 Child } & 0.032 & -0.078 & -0.015 \\
\hline & 0.41 & -0.81 & -0.15 \\
\hline \multirow[t]{2}{*}{2 Children } & -0.026 & -0.016 & 0.023 \\
\hline & -0.56 & -0.34 & 0.41 \\
\hline \multirow[t]{2}{*}{3 Children } & 0.022 & -0.06 & 0.009 \\
\hline & 0.54 & -1.34 & 0.17 \\
\hline 4 or more Children & 0 & 0 & 0 \\
\hline \multirow[t]{2}{*}{ Missing Education } & 0 & -0.018 & -0.182 \\
\hline & & -0.11 & -1.15 \\
\hline \multirow[t]{2}{*}{$\mathrm{BA}$} & 0.002 & 0.07 & 0.002 \\
\hline & 0.03 & 1.12 & 0.02 \\
\hline \multirow[t]{2}{*}{$\mathrm{M}(\mathrm{B}) \mathrm{A}$} & 0.049 & $0.130 *$ & -0.004 \\
\hline & 0.81 & 1.94 & -0.05 \\
\hline \multirow[t]{2}{*}{ Doctorate } & 0.033 & 0.055 & 0.005 \\
\hline & 0.49 & 0.73 & 0.06 \\
\hline \multirow[t]{2}{*}{ Fashion \& Retail } & -0.02 & -0.03 & $-0.273 * * *$ \\
\hline & -0.32 & -0.48 & -3.51 \\
\hline \multirow[t]{2}{*}{ Automotive and Manufacturing } & -0.046 & -0.04 & -0.071 \\
\hline & -0.89 & -0.71 & -0.89 \\
\hline Media & 0.125 & 0.043 & 0.144 \\
\hline
\end{tabular}




\begin{tabular}{|l|r|r|r|}
\hline & 1.42 & 0.51 & 1.58 \\
\hline Telecom \& Technology & 0.112 & $0.151^{* *}$ & 0.101 \\
\hline & 1.64 & 2.03 & 1.3 \\
\hline Services & -0.066 & -0.023 & -0.04 \\
\hline & -1.33 & -0.39 & -0.54 \\
\hline Energy \& Oil \& Metals and Mining & 0.125 & $0.165^{*}$ & 0.035 \\
\hline & 1.45 & 1.9 & 0.39 \\
\hline R Adj sq. & 0.153 & 0.174 & 0.17 \\
\hline N & 394 & 405 & 405 \\
\hline
\end{tabular}

Logit regressions with signing the Giving Pledge (GP), presence in the Philanthropy Top 50 or presence in the Million Dollar list as dependent variable. Average marginal effects are given in the table, $\mathrm{t}$ stats are under the coefficients, stars reflect significance level $(* 0.1 * *$ $0.05 * * * 0.01)$ 
OA5 - Table 3 - Explaining Very Big Ticket Items Consumption

Table 3 in the paper shows that on average, self-made billionaires spend more on very big ticket items like yachts, jets and art. Here we run regressions like for charitable giving (table 2 in the paper) but using consumption of these very big ticket items as dependent variable. The coefficient of self-made is always positive and in some cases significant.

\begin{tabular}{|c|c|c|c|c|c|c|c|c|}
\hline & \multicolumn{8}{|c|}{ Logit Regressions (all dependent variables are dummies) } \\
\hline & Big Cons. & Yachts & Jets & Art & $\begin{array}{l}\text { Big Cons. } \\
\text { US only }\end{array}$ & $\begin{array}{l}\text { Yachts } \\
\text { US only }\end{array}$ & $\begin{array}{r}\text { Jets } \\
\text { US only }\end{array}$ & $\begin{array}{r}\text { Art } \\
\text { US only }\end{array}$ \\
\hline \multirow[t]{2}{*}{ Self-made } & 0.021 & 0.012 & 0.02 & 0.002 & $0.079 *$ & 0.009 & $0.060^{*}$ & 0.04 \\
\hline & 1.23 & 0.99 & 1.57 & 0.18 & 1.86 & 0.28 & 1.91 & 1.12 \\
\hline \multirow[t]{2}{*}{ Connections } & $0.006 * * *$ & $0.002 *$ & $0.002 * * *$ & $0.003 * * *$ & $0.008 * * *$ & $0.003^{*}$ & $0.003^{* *}$ & $0.005^{* * *}$ \\
\hline & 4.54 & 1.71 & 2.6 & 4.13 & 4.16 & 1.72 & 2.35 & 3.6 \\
\hline \multirow[t]{2}{*}{ Net Worth } & $0.008 * * *$ & $0.003^{* * * *}$ & $0.003^{* * * *}$ & $0.002 * * *$ & $0.010^{* * *}$ & 0.002 & $0.006^{* * * *}$ & 0.001 \\
\hline & 6.61 & 3.89 & 5.32 & 2.94 & 4.37 & 1.54 & 4.19 & 0.88 \\
\hline \multirow[t]{2}{*}{ Age } & -0.001 & 0 & $-0.001 * *$ & 0 & $-0.002 *$ & 0.001 & $-0.002 * *$ & -0.001 \\
\hline & -1.18 & 0.05 & -2.48 & -0.85 & -1.74 & 0.57 & -2.33 & -0.63 \\
\hline \multirow[t]{2}{*}{$\begin{array}{l}\text { Missing } \\
\text { Age } \\
\end{array}$} & 0.022 & 0.051 & 0 & -0.024 & 0 & 0 & 0 & 0 \\
\hline & 0.37 & 1.22 & & -0.5 & & & & \\
\hline \multirow[t]{2}{*}{ US Citizen } & 0.002 & -0.007 & 0 & 0 & 0 & 0 & 0 & 0 \\
\hline & 0.12 & -0.51 & 0.03 & 0 & & & & \\
\hline \multirow[t]{2}{*}{$\begin{array}{l}\text { Family } \\
\text { Wealth } \\
\end{array}$} & 0 & -0.003 & -0.031 & 0.01 & -0.118 & -0.025 & 0.005 & 0 \\
\hline & 0.01 & -0.17 & -1.17 & 0.67 & -1.08 & -0.46 & 0.12 & \\
\hline \multirow[t]{2}{*}{$\begin{array}{l}\text { In a } \\
\text { Relationship } \\
\end{array}$} & -0.017 & 0 & -0.014 & $-0.031 * *$ & -0.007 & 0.03 & $-0.051 * *$ & -0.029 \\
\hline & -0.89 & 0.02 & -1.2 & -2.57 & -0.17 & 0.91 & -2.06 & -0.89 \\
\hline \multirow[t]{2}{*}{$\begin{array}{l}\text { Missing } \\
\text { Relation } \\
\end{array}$} & -0.082 & -0.055 & 0 & -0.037 & 0 & 0 & 0 & 0 \\
\hline & -1.39 & -1.2 & & -0.94 & & & & \\
\hline \multirow[t]{2}{*}{1 Child } & -0.037 & -0.024 & -0.024 & -0.002 & -0.01 & 0.031 & 0.035 & 0 \\
\hline & -0.99 & -0.87 & -0.87 & -0.07 & -0.1 & 0.58 & 0.64 & . \\
\hline \multirow[t]{2}{*}{2 Children } & 0.034 & 0.019 & 0.014 & 0.022 & 0.041 & 0.007 & 0.053 & -0.024 \\
\hline & 1.34 & 1.06 & 0.88 & 1.14 & 0.6 & 0.17 & 1.28 & -0.46 \\
\hline \multirow[t]{2}{*}{3 Children } & 0.012 & -0.008 & 0.002 & 0.012 & -0.019 & -0.074 & 0.066 & -0.059 \\
\hline & 0.45 & -0.4 & 0.1 & 0.61 & -0.29 & -1.48 & 1.63 & -1.16 \\
\hline \multirow[t]{2}{*}{$\begin{array}{l}4 \text { or more } \\
\text { Children }\end{array}$} & -0.001 & -0.014 & 0.001 & 0.018 & -0.038 & -0.081 & 0.053 & -0.054 \\
\hline & -0.05 & -0.7 & 0.04 & 0.91 & -0.55 & -1.56 & 1.34 & -1.06 \\
\hline \multirow[t]{2}{*}{$\begin{array}{l}\text { Missing } \\
\text { Education } \\
\end{array}$} & $-0.085^{* * * *}$ & $-0.050 * * *$ & $-0.051 * * *$ & 0.001 & 0 & 0 & 0 & 0 \\
\hline & -3.15 & -2.64 & -2.91 & 0.03 & & & & \\
\hline \multirow[t]{2}{*}{$\mathrm{BA}$} & $-0.047 * *$ & $-0.038 * *$ & $-0.042 * * *$ & 0.033 & $-0.073 *$ & $-0.063 * *$ & $-0.077 * * *$ & 0.083 \\
\hline & -2.01 & -2.23 & -3.08 & 1.42 & -1.8 & -2.06 & -3.05 & 1.62 \\
\hline
\end{tabular}




\begin{tabular}{|l|r|r|r|r|r|r|r|}
\hline $\mathrm{M}(\mathrm{B}) \mathrm{A}$ & $-0.095 * * *$ & $-0.069 * * *$ & $-0.039 * * *$ & 0.005 & $-0.168 * * *$ & $-0.060 *$ & $-0.069 * *$ \\
& -3.42 & -3.1 & -2.62 & 0.21 & -3.29 & -1.74 & -2.48 \\
\hline \\
\hline
\end{tabular}

The dependent variable is a dummy that is 1 for those consuming conspicuously (on yachts, jets or art). Average marginal effects of Logit regressions are given in the table, $\mathrm{t}$ stats are under the coefficients, stars reflect significance level (*0.1**0.05***0.01). The variables related to missing age, relationship status and education are excluded as explanatory variables if they perfectly predict the dependent variable. Industry Dummies are available in both regressions (10 industries for the regression with all billionaires, 7 industries if only U.S billionaires are included).

OA5 - Table 4 - including Very Big Ticket Items as additional variable

In table 4 , we including a dummy that is 1 if a billionaires also spent money on yachts, art of jets as an additional variable. This does not affect the importance of the self-made dummy, however.

\begin{tabular}{|c|c|c|c|}
\hline & \multicolumn{3}{|c|}{ Logit Regressions } \\
\hline & GP $(1 / 0)$ & Top $50(1 / 0)$ & Million $\$(1 / 0)$ \\
\hline \multirow[t]{2}{*}{ Self-made } & $0.194 * * *$ & $0.189 * * *$ & 0.055 \\
\hline & 3.36 & 3.61 & 1.13 \\
\hline \multirow[t]{2}{*}{ \# Connections } & $0.006 * *$ & $0.008 * * *$ & $0.013 * * *$ \\
\hline & 2.51 & 3.19 & 3.52 \\
\hline \multirow[t]{2}{*}{ Net Worth } & $0.005 * *$ & $0.010 * * *$ & $0.013 * *$ \\
\hline & 2.08 & 3.3 & 2.45 \\
\hline \multirow[t]{2}{*}{ Age } & 0.002 & $0.006^{* * *}$ & $0.010 * * *$ \\
\hline & 1.25 & 3.58 & 5.96 \\
\hline \multirow[t]{2}{*}{ Family Wealth } & -0.135 & 0.001 & 0.025 \\
\hline & -1.05 & 0.02 & 0.26 \\
\hline \multirow[t]{2}{*}{ In a Relationship } & -0.04 & -0.034 & -0.011 \\
\hline & -0.88 & -0.71 & -0.19 \\
\hline \multirow[t]{2}{*}{ Missing Children } & 0 & 0 & -0.145 \\
\hline & & . & -0.77 \\
\hline \multirow[t]{2}{*}{1 Child } & -0.052 & -0.178 & -0.018 \\
\hline & -0.54 & -1.57 & -0.14 \\
\hline \multirow[t]{2}{*}{2 Children } & -0.113 & -0.118 & 0.006 \\
\hline & -1.57 & -1.55 & 0.06 \\
\hline \multirow[t]{2}{*}{3 Children } & -0.065 & $-0.162 * *$ & 0.001 \\
\hline & -0.93 & -2.14 & 0.01 \\
\hline \multirow[t]{2}{*}{4 or more Children } & -0.087 & -0.102 & -0.008 \\
\hline & -1.24 & -1.36 & -0.08 \\
\hline Missing Education & 0 & -0.072 & -0.223 \\
\hline
\end{tabular}




\begin{tabular}{|c|c|c|c|}
\hline & & -0.44 & -1.53 \\
\hline \multirow[t]{2}{*}{$\mathrm{BA}$} & -0.031 & 0.05 & -0.001 \\
\hline & -0.59 & 0.87 & -0.02 \\
\hline \multirow[t]{2}{*}{$\mathrm{M}(\mathrm{B}) \mathrm{A}$} & 0.016 & $0.108^{*}$ & 0.018 \\
\hline & 0.28 & 1.76 & 0.24 \\
\hline \multirow[t]{2}{*}{ Doctorate } & 0.012 & 0.046 & 0.042 \\
\hline & 0.2 & 0.66 & 0.53 \\
\hline \multirow[t]{2}{*}{ Fashion \& Retail } & -0.019 & -0.027 & $-0.263 * * *$ \\
\hline & -0.3 & -0.44 & -3.55 \\
\hline \multirow[t]{2}{*}{ Automotive and Manufacturing } & -0.057 & -0.049 & -0.073 \\
\hline & -1.09 & -0.89 & -0.94 \\
\hline \multirow[t]{2}{*}{ Media } & 0.102 & 0.043 & 0.127 \\
\hline & 1.23 & 0.55 & 1.47 \\
\hline \multirow[t]{2}{*}{ Telecom \& Technology } & $0.128 *$ & $0.151^{* *}$ & 0.104 \\
\hline & 1.9 & 2.14 & 1.45 \\
\hline \multirow[t]{2}{*}{ Services } & -0.06 & -0.019 & -0.04 \\
\hline & -1.13 & -0.33 & -0.56 \\
\hline \multirow[t]{2}{*}{ Energy \& Oil \& Metals and Mining } & 0.079 & $0.168 * *$ & 0.053 \\
\hline & 0.99 & 1.98 & 0.65 \\
\hline \multirow[t]{2}{*}{ Very Big Ticket Items Consumption } & -0.056 & 0.018 & $0.161 * *$ \\
\hline & -1.06 & 0.35 & 2.32 \\
\hline R Adj sq. & 0.147 & 0.181 & 0.191 \\
\hline $\mathrm{N}$ & 419 & 431 & 440 \\
\hline
\end{tabular}

Logit regressions with signing the Giving Pledge (GP), presence in the Philanthropy Top 50 or presence in the Million Dollar list as dependent variable. Average marginal effects are given in the table, $\mathrm{t}$ stats are under the coefficients, stars reflect significance level $(* 0.1 * *$ $0.05 * * * 0.01$ ). The variables related to missing age, relationship status and education are excluded as explanatory variables if they perfectly predict the dependent variable. 
